\title{
ANALISANDO A CIDE-CONDECINE LICENÇA A PARTIR DAS CONSEQUENCIAS DA SUA INCIDÊNCIA NO SEGMENTO DE VIDEO POR DEMANDA PROGRAMADO (VOD - NETFLIX) ${ }^{*}$
}

Vinícius Alves Portela Martins ${ }^{* *}$

Resumo: Esse artigo tem por objetivo analisar as consequências da incidência e da não incidência da Condecine Licença (art. 32, I da MP 2.228-1/2001) sobre os agentes que atuam no segmento de vídeo por demanda programado (vídeo on demand"'-VOD). Para isso, traremos noções básicas sobre pragmatismo e consequencialismo, inclusive sua aplicação no direito tributário. Depois, apontaremos características do setor audiovisual e do segmento de VOD. $\mathrm{Na}$ terceira parte, será descrita a Condecine Licença para que, ao final, discutamos as consequências da incidência e não-incidência Condecine Licença, apontando também os efeitos sobre os princípios jurídicos informadores dessa espécie tributária. Ao final, uma breve conclusão quanto as possibilidades futuras da incidência dessa exação sobre o audiovisual e o referido segmento.

Palavras-chave: CIDE, Condecine, consequencialismo, pragmatismo jurídico, vídeo on demand, Ancine.

\begin{abstract}
This article aims to analyze Condecine's (art. 32, I da MP 2.228-1/2001) incidence or not on the video on demand segment. To do that, we'll talk about the pragmatism, including you relation with tax law. Then we quickly analyze the audiovisual sector, focusing on the video on demand segment. Then we describe the characteristics of Condecine in order to finally discuss the consequences of tax incidence or not in the VOD segment, including the effects on the principles relation to this specific tax. Finally, we conclude presenting new possibilities of this tax incident on VOD and in the audiovisual sector.
\end{abstract}

Key word - Tax, Condecine, Pragmatism, video on demand, Ancine.

Sumário: Introdução. 1-Pragmatismo e Consequencialismo. 1.2) Pragmatismo e consequencialismo no direito tributário; 2-Segmento de mercado de VOD (Netflix). 3 A contribuição de intervenção no domínio econômicoCIDE Contribuição para o Desenvolvimento da Indústria Cinematográfica Nacional - Condecine (art. 32, II da MP 2.228-1/2001) 4. A problemática da incidência e da não incidência da Condecine Licença tendo em vista as consequências geradas pela mesma no segmento de vídeo por demanda. 4.1 Considerações quanto ao uso do método consequencialista na análise da incidência da Condecine Licença (art. 32, I da MP 2.228-1/2001). 4.2 A análise consequencialista da incidência da Condecine Licença (art. 32, I da MP 2.228-1/2001) sobre segmento de VOD. 4.3- Breves considerações sobre a estrutura tributária da Condecine licença e sua relação com as possíveis consequências da incidência e não incidência da Condecine Licença no mercado de VOD. Conclusão

\footnotetext{
*Artigo submetido em 16 abr. 2018 e aceito para publicação em 11 mai. 2018.

*** Especialista em Regulação (ANCINE), Mestre em Políticas Públicas pelo Instituto de Economia da UFRJ, Rio de Janeiro, RJ, Brasil.
}

Revista de Finanças Públicas, Tributação e Desenvolvimento - RFPTD, v. 6, n.6, 2018 


\section{Introdução}

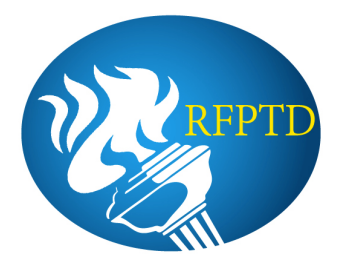

Esse artigo tem por objetivo analisar as consequências da incidência e da não incidência da Condecine Licença (art. 32, I da MP 2.228-1/2001) sobre os agentes que atuam no segmento de vídeo por demanda programado (vídeo on demand-VOD) onde, no Brasil, o principal exemplo hoje é o Netflix, analisando os efeitos derivados da incidência/não-incidência ajudam na concretização dos princípios informadores dessa espécie, notadamente os previstos no art. 170 (em especial a livre iniciativa e a livre concorrência), além de outros.

As contribuições de intervenção no domínio econômico, tributo de competência exclusiva da União, têm por finalidade corrigir descompassos e falhas de mercado inerentes a determinados setores. Sua intervenção, entretanto, pode ser avaliada de suas formas: a primeira (escolhida no presente trabalho) a partir dos efeitos que a incidência tributária impõe aos agentes de um determinado domínio econômico. A segunda, através da aplicação dos recursos arrecadados nesse segmento. A análise de consequências da intervenção ocasionada pela incidência tributária é de fundamental valia para que se avalie, de fato, se a intervenção ocasionada por essa espécie, efetivamente, cumpre seu papel ou é apenas mais um meio de arrecadação da União que tanto fere o complexo e injusto sistema tributário nacional.

Para isso, traremos noções básicas sobre pragmatismo e consequencialismo, inclusive sua aplicação no direito tributário, de forma verificar as possibilidades de aplicação e o respectivo desenvolvimento desse pensamento neste campo. Depois, apontaremos características básicas do setor audiovisual e do segmento de VOD, de forma a conhecermos a sua dinâmica o que permitirá, posteriormente, avaliar os efeitos da incidência e da não incidência sobre este setor, inclusive e principalmente o segmento de VOD.

$\mathrm{Na}$ terceira parte, será descrita as características básicas da CIDE- Condecine Licença para que, ao final, discutamos as consequências da incidência e não-incidência desta espécie de CIDE, relacionando às com a possibilidade de concretização ou não aos princípios constitucionais informadores das CIDE e da própria Condecine. Ao final, uma breve conclusão quanto as possibilidades futuras da incidência dessa exação sobre o audiovisual (inclusive VOD), a partir da análise da estrutura da Condecine.

\section{1-Pragmatismo e Consequencialismo}

Quanto a sua origem etimológica (considerando sua própria polissemia), o pragmatismo pode ser sucintamente entendido como meio de resolução de um problema, tendo uma utilidade 


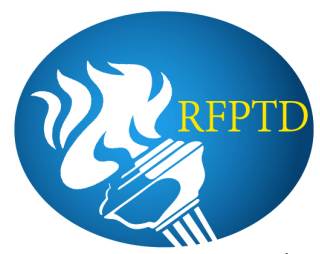

prática e também representando um método para isso ${ }^{1}$. O pragmatismo filosófico ${ }^{2}$ surge no final do século XIX nos EUA ${ }^{3}$, idealizado por Charles Sanders Peirce e Willian James ${ }^{4}$ ("Metaphysicalclub in Havard”). A origem para esse tipo de pensamento voltado a aspectos mais prático está na formação de Charles Peirce ${ }^{5}$, o que seria atenuado por Willian James, também entre outras razões, em virtude sua formação mais humanista ${ }^{6}$. Após um breve hiato na primeira metade do século XX, o movimento volta a ganhar força como corrente filosófica ao final da década de 70, notadamente com o trabalho dos autores como Richard Rorty, Hilary Putnan e Robert Brandom ${ }^{7}$, após um período de declínio no aspecto acadêmico ${ }^{8}$.

\footnotetext{
${ }^{1}$ Kinouchi (2018, p. 1): "O pragmatismo pode ser sucintamente entendido como sendo, de certo modo, um expediente - que por sua vez significa um "meio de sair de um embaraço, de vencer uma dificuldade, de lograr bom êxito em alguma coisa" (Weiszflog, 1998, p. 922). Por um lado, o expediente certamente tem sua utilidade prática; e, por outro, trata-se de uma regra ou de uma fórmula para lidar com questões que demandam uma solução. No final das contas, um expediente transmite a ideia de um método para abordar os problemas. Desse modo, para apreendermos o sentido completo da palavra pragmatismo, temos sim que considerar o papel da utilidade prática, mas não podemos esquecer que o pragmatismo se coloca, antes de tudo, como uma questão de método." KINOUCHI, Renato Rodrigues. Notas Introdutórias ao pragmatismo clássico. Disponível em: $<$ http://www.scielo.br/pdf/ss/v5n2/a04v5n2.pdf> acesso em: 05 de abril.2018.

2 O pragmatismo jurídico de Richard Posner, a princípio, é diferente das contribuições filosóficas clássicas elaboradas por Charles Sanders Peirce, William James e John Dewey - denominados aqui de pragmatismo filosófico, ainda que segundo Mendonça $(2014$, P. 48) haja relação entre eles, posição com a qual concordamos: "o pragmatismo que realmente serve ao direito, na visão de Posner, não é a filosofia acadêmica, nova ou antiga, mas um pragmatismo cotidiano. Uma disposição de espírito "sem frescuras", direto à ação", com pouca paciência para teorias. Não que o pragmatismo filosófico seja incompatível com tal postura; é compatível, mas independente. As diferenças são institucionais...”. MENDONÇA, José Vicente Santos de. Direito Constitucional econômico: a intervenção do estado na economia à luz da razão pública e do pragmatismo. $1^{\text {a }}$. Edição. MG-Belo Horizonte Editora Fórum. 2014. P. 48.

${ }^{3}$ Entretanto, importante destacar que não fica restrito a este país. Com base no texto Pragmatism, temos que "It would be wrong to conclude that pragmatism was restricted to the United States or hat the only important pragmatist thinkers were Pierce, James and Dewey. As is documented by Thayer, there were pragmatist in Oxford, in France, and especially in Italy in the early years of the twenty century. Com base no texto Pragmatism disponível em $<$ https://plato.stanford.edu/entries/pragmatism/:> acesso em: 05 de abril. 2018.

${ }^{4}$ E posteriormente John Dewey, o qual foi influenciado por desses dois autores sendo, entretanto, 20 anos mais novo, o que permitiu ser o grande nome do pragmatismo do século XX.

${ }^{5}$ Kinouchi (2018, p.2) ensina: "se examinarmos a trajetória intelectual de Peirce, veremos que a maior parte de sua vida foi dedicada a questões ligadas à ciência, tanto no campo teórico como no experimental. No campo teórico, ele investigava questões principalmente ligadas à matemática e à lógica[...]cabe remarcar que Peirce não foi apenas um filósofo bem informado em ciência. Ele foi realmente um pesquisador profissional e, com efeito, para ele o método científico oferece a maneira mais apropriada de raciocinar. " KINOUCHI, Op. cit. Disponível em $<$ http://www.scielo.br/pdf/ss/v5n2/a04v5n2.pdf> acesso em: 05 de abril.2018.

${ }^{6}$ Kinouchi $(2018$, p.2) aponta, quanto a Willian James que: "Convém assinalar que James também foi um "homem de ciência", embora de uma maneira diferente de Peirce. A principal diferença, que terá consequências profundas para o desenvolvimento de suas respectivas visões filosóficas, é que a formação de James, em medicina, biologia e psicologia - e não em física e matemática - fez com que ele tivesse uma perspectiva mais nominalista a respeito da ciência, em oposição ao realismo de Peirce..." KINOUCHI, Op. cit. Disponível em $<$ http://www.scielo.br/pdf/ss/v5n2/a04v5n2.pdf> acesso em: 02 de abril. 2018. p. 2

${ }^{7}$ Com base no texto Pragmatism disponível em $<$ https://plato.stanford.edu/entries/pragmatism/ $>$ : acesso em: $05 \mathrm{de}$ abril.2018.

${ }^{8}$ Mendonça (2014, P. 39) sobre esse aspecto, comenta: [...]lá pela metade do século XX, o pragmatismo já era considerado, no mercado de ideias, carta fora do baralho; resíduo ingênuo de um liberalismo desacreditado pelas
} 


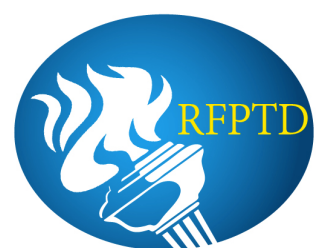

A máxima pragmatista diz respeito à necessidade de se analisar os fatos a partir das consequências práticas deste. ${ }^{9} \mathrm{Um}$ dos objetivos inicialmente era resolver as supostas contradições entre ciência, moral e religião ${ }^{10}$, trazendo esta análise prática para a resolução dos problemas concretos. O método pragmático, assim, buscaria resolver a aparente falta de efetividade na resolução de problemas práticos comparada à filosofia tradicional, dualista, clarificando conceitos e hipóteses que pareciam insolúveis, através da demonstração das consequências observadas ${ }^{11}$.Mendonça $(2014$, p. 36) esclarece de forma didática os principais objetivos do pragmatismo filosófico que:

Seu propósito, se é que assim se pode falar de uma filosofia tão multitarifária, é o de resgatar o valor da experiência: num mundo cindindo em dualismos anódinos - objetos mentais versus mundo extrametal, teoria versus pratica, cultura humanística versus cultura cientifica -, o pragmatismo quer depurar nossa compreensão de conceitos viciadamente abstratos. Como há continuidade e não separação entre teoria e prática, depurar nossos conceitos de muitas noções vagas que muitas correntes filosóficas fizeram correr em nossa consciência cotidiana - e isso, por intermédio de um apelo a que olhemos as consequências concretas da adoção desta ou daquela proposição -, é, ao mesmo tempo, contribuir para que o pensamento possa ser mais eficaz e a conduta mais inteligente..."

Interessante para nosso trabalho, tendo em vista o foco na análise consequencialista ${ }^{13} \mathrm{da}$ incidência da Condecine Licença (art. 32, II da MP 2.228-1/2001) no mercado de VOD (Netfix), é a apresentação da matriz pragmática, trazida por Pogrebinschi ${ }^{14}$ : o antifundacionalismo, o consequencialismo e o contextualismo (matriz também citada por Mendonça ${ }^{15}$ ). O

guerras mundiais e pela depressão econômica, já devidamente expurgado do âmbito acadêmico...”. MENDONÇA, 2014 , p.39.

9 "The pragmatist maxim is a distinctive rule or method for becoming reflectively clear about the contents of concepts and hypotheses: we clarify a hypothesis by identifying it's pratical consequences" Com base no texto Pragmatism disponível em https://plato.stanford.edu/entries/pragmatism/<acessadoem> 04/04/2018

10 "The challenge is to show how to reconcile "the scientific loyalty do facts" with "the old confidence in human values and the resultant spontaneity, weather of the religious of the romantic type...". Pragmatism disponível em: $<$ https://plato.stanford.edu/entries/pragmatism/> acesso em: 05 de abril.2018.

11 "James never worked out his understanding of "praticals consequences", as fully as Pierce did.." Pragmatism disponível em: $<$ https://plato.stanford.edu/entries/pragmatism/> acesso em: 05 de abril.2018.

${ }^{12}$ MENDONÇA, 2014. p. 36

${ }^{13}$ Para nosso estudo, utilizaremos como base o conceito amplo de consequencialismo trazido por Schuartz (2008, p.2) como "qualquer programa teórico que se proponha a condicionar, ou qualquer atitude que condicione explícita ou implicitamente a adequação jurídica de um determinada decisão judicante à valoração das consequências associadas à mesma e às suas alternativas....será tratada como consequencialista tanto a posição que reserva a valoração das consequências da decisão um papel residual no referido juízo de adequação...quanto aquela que admite ao lado da análise consequencialista e com um peso maior ou menor no processo decisório, formas diferentes de argumentação... SCHUARTZ, Luis Fernando. Consequencialismo Jurídico, Racionalidade Decisória e Malandragem. Rio de Janeiro. Revista de Direito administrativo. Vol. 248. Ed. Fundação Getúlio Vargas. 2008, p. 130. < http://bibliotecadigital.fgv.br/ojs/index.php/rda/article/view/41531/40881 > acesso em: 01 de abril.2018.

${ }^{14}$ POGREBINSCHI Thamy. Teoria social e política. $1^{\text {a }}$. Ed. RJ. Ed. Relume dumará, 2005.

${ }^{15}$ Mendonça $(2014$, p. 39) relaciona essas três características vistas acima, trazendo-nos uma matriz básica do pragmatismo: "Eis que a matriz pragmatista se completa. Se não existem fundações que justifiquem ou validem

Revista de Finanças Públicas, Tributação e Desenvolvimento - RFPTD, v. 6, n.6, 2018 


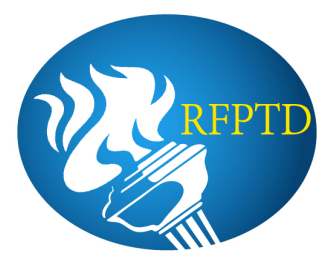

antifundacionalismo refere-se rejeição dos dogmas, considerando, sim, que as verdades são criadas e não encontradas, além de não objetiva. O consequencialismo prioriza as consequências do ato ou teoria ou conceito, devendo o significado e a verdade serem analisados a partir da diferença que fazem na realidade. E o contextualismo trata do destaque ao contexto político, social, histórico e cultural, prezando pela diferença prática que as teorias possam fazer de fato (MENDONÇA, 2014, P. 38). Essa matriz é fundamental, pois ela nos traz as diretrizes básicas desse pensamento, estando interligadas de forma bastante forte. E também serão úteis na análise consequencialista da incidência da Condecine Licença que faremos na última parte.

Quanto ao pragmatismo jurídico (influenciado pelo pragmatismo filosófico), destaca-se a obra do autor americano Richard Posner, ainda que alguns autores ${ }^{16}$ considerem que os escritos de Oliver Holmes Jr tenham sido as primeiras demonstrações de transposições das teses e concepções do pragmatismo filosófico para o direito. Santini (2011, p.175) traz as ideias que marcam o pensamento de Richard Posner:

\footnotetext{
“...i-sua postura relativista com relação a moral; ii-as críticas ao moralismo acadêmico, notadamente quanto a sua inépcia pragmática; iii-a postura cética quanto a invocação da autoridade de textos clássicos na busca de soluções de problemas atuais; e iv-a rejeição à importância na identificação de sobreposições parciais havidas entre deveres morais e deveres jurídicos.... ${ }^{17}$.
}

Reitera-se um pensamento voltado para o efeito prático de decisões no campo do direito (ou dando maior ênfase a este), criticando-se posições fundacionalistas, dualistas ou ligadas excessivamente aos aspectos morais, sem que relacionadas a um efeito prático, o que o aproxima, nesse sentido, do pragmatismo filosófico, inclusive quanto a sua matriz básica supracitada $^{18}$. Dessa forma, percebe-se a importância do pragmatismo como parâmetro a ser

conceitos ou teorias, deve-se apreciá-las a partir de suas consequências, as quais só adquirem sentido dentro do contexto no qual estão inseridas. Os deuses estão mortos; é hora de se preocupar com as consequências concretas de nossos conceitos, juízos, ações, praticados por nós em nosso único mundo...” MENDONÇA, 2014. p. 39.

${ }^{16}$ Freire (2018, p. 25) ensina que "os escritos de Oliver Holmes Jr tenham sido as primeiras demonstrações de transposições das teses e concepções do pragmatismo filosófico para o direito". FREIRE, Alonso Reis. Odisseu ou Hercules? Sobre o pragmatismo e a análise econômica do direito de Richard A Posner. Disponível em $<$ http://periodicos.pucminas.br/index.php/DireitoSerro/article/view/1996/2179> acesso em: 01 de abril.2018.

${ }^{17}$ BRANDO, Marcelo Santini. A crítica da vertente econômica à teoria de justiça de John Rawls. Revista de Direito da procuradoria Geral do RJ. Vol. 66, 2011. P. 175.

${ }^{18}$ Não obstante as mais variadas formas de pragmatismo, todas elas apresentam três características comuns, a saber: a) antifundacionalismo: rejeição à presença de entidades metafísicas ou conceitos abstratos, imunes às transformações sociais; b) contextualismo: baseando-se a interpretação jurídica em questões práticas, vendo o direito como efetiva prática social;e c) consequencialismo: deve-se observar as consequências práticas na tomada de decisões (olhando para o futuro e não para o passado) - OLIVEIRA, Rafael Carvalho Rezende. A releitura do direito administrativo a luz do pragmatismo jurídico. rda - revista de Direito Administrativo, Rio de Janeiro, v. 256, p. 129-63, jan./abr. 2011.

$<$ http://bibliotecadigital.fgv.br/ojs/index.php/rda/article/viewFile/8496/7245>; acesso em: 05 de abril. 2018. p. 132

Revista de Finanças Públicas, Tributação e Desenvolvimento - RFPTD, v. 6, n.6, 2018 


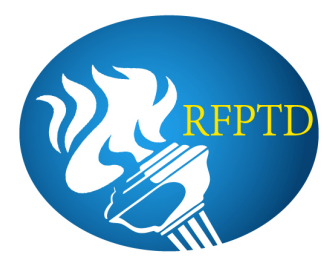

utilizado para interpretação e aplicação das normas jurídicas, especialmente no mundo contemporâneo, de forma a que se resolva problemas de ordem prática, buscando atenuar as influências ideológicas, considerando as possíveis consequências de certas decisões, dentro de um contexto específico e variável ${ }^{19}$.

Quanto às críticas feitas ao pragmatismo tem-se: i- o uso do utilitarismo ligado a sua forma de decidir, o que violaria no caso em concreto (ou não se importaria) com os valores e princípios fundamentais; ii- a ampliação do poder discricionário do juiz, deixando de ser esta a boca da lei ou principialista prático; iii - a ineficiência em termos de resultado, pois o formalismo seria o caminho mais prático para se produzir melhores consequências (além de mais seguras) e iv- instrumentalismo que derrotaria a ideia de bem comum ${ }^{20}$. Walter Kennedy, apud Mendonça (2014, p.68-69), diz que o pragmatismo “é, em certa medida, anárquico e desprovido de standards ou princípios, quando o direito requer um razoável grau de uniformidade, estabilidade e certeza..." ${ }^{21}$. Ou seja, o pragmatismo seria fonte de incerteza no direito por representar decisionismo judicial onde o utilitarismo, casuístico, seria o principal fundamento da decisão do juiz.

Ronald Dworking também criticou de forma forte tanto a $\mathrm{AED}^{22}$ como o pragmatismo jurídico. Na mesma linha da apresentada acima, traz que a análise econômica do direito pressupõe, implicitamente, uma justificação moral da tese da maximização da riqueza da sociedade, independentemente de como essa riqueza está concentrada ou distribuída, representando assim um valor político com prioridade sobre os demais. No caso especifico do pragmatismo jurídico, o autor aponta que há neste a crença moral que o autor americano tanto combate, querendo, na verdade, fazer prevalecer a sua teoria moral:

Ele (Richard Posner) pede a morte da teoria moral, mas, como todos os pretensos coveiros da filosofia, deseja apenas o triunfo de sua própria teoria. Seus argumentos mostram o contrário do que ele pretendia: mostram que a teoria moral não pode ser eliminada e que a perspectiva moral é

\footnotetext{
${ }^{19}$ Apesar de possuir bases semelhantes, não se deve confundir a análise econômica do direito - AED, que também tem em Richard Posner um de seus precursores, com o pragmatismo jurídico. Primeiro porque cronologicamente, o pragmatismo é posterior; segundo que a AED, a qual tem origem estudos de Ronald Coase sendo intimamente ligada a economia tem como finalidade a ser atingida (ou como parâmetro de busca) a eficiência econômica maximização da riqueza.

${ }^{20}$ MENDONÇA, 2014. P. 68-69.

${ }^{21}$ MENDONÇA, 2014. P. 68-69.

${ }^{22}$ Neste caso, Dworking critica a maximização da riqueza como valor a ser alçado como mais importante que outros valores: "As afirmações de que a riqueza social é o próprio valor social ou pelo menos um dos seus componentes são ideias defensáveis? Se a Análise Econômica do Direito defende que as decisões judiciais devem ser tomadas de modo a aumentar a riqueza social, então deve ela demonstrar por que uma sociedade mais rica é melhor ou está em melhor situação que uma sociedade menos rica." FREIRE, 2018. p. 41.
} 


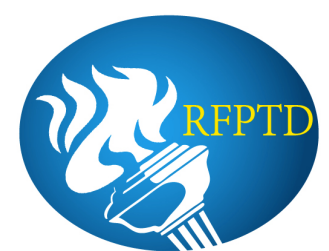

indispensável, mesmo para o ceticismo ou o relativismos morais. O próprio Posner é guiado por uma crença moral tácita, dissimulada e pouco atraente, porém inexorável. ${ }^{23}$

Modernamente, mais ligado ao consequencialismo, há críticas ao fato deste ser utilizado mais como um estilo de decisão (que considera consequências) que como um dos parâmetros de controle de decisão (que procura de fato estudá-las de forma mais profunda, identificando, medindo e comparando-as ${ }^{24}$ para aí sim tomar decisões).

Estas críticas também possuem problemas, pois num contexto de consequencialismo fraco $^{25}$, deve destinar-se aos hard cases (casos de decisões difíceis, com alto grau de ambivalência ${ }^{26}$ ), temos, aí sim, um aumento de ganho intelectual por parte do responsável pela decisão, na medida em que este demandará conhecimento de doutrina, precedentes, legislação, usando-os de forma pragmática, inclusive através do uso de conteúdos interdisciplinares. Neste sentido, a decisão tende a ter um grau de motivação muito maior, sendo este estimulado pelo pragmatismo - aumentando, inclusive, a intelectualidade dos aplicadores do direito ${ }^{27}$. Ademais, não nos parece violador do direito à medida em que deve buscar concretizar os valores e princípios constitucionais.

Como sugere Mendonça, deve incidir o pragmatismo em consequências que possam ser reconduzidas à constituição ${ }^{28}$. Assim, as consequências deverão ser integralmente compatíveis, o que reduz as críticas relativas à não valoração de princípios. As consequências a serem

\footnotetext{
${ }^{23}$ DWORKIN, Ronald. A justice de toga. São Paulo: Martins Fontes, 2010, p.133.

24 "O segundo futuro é mais provável do que o primeiro. É o futuro do cumprimento insincero desta nova Lei de Introdução. $\mathrm{O}$ art. 20, caput, não traria dever real de medição das consequências práticas da decisão, mas dever de utilização de uma retórica de consequências. Desse modo, o comando não se decidirá com base em valores jurídicos abstratos sem medir as consequências práticas da decisão seria lido como não se decidirá sem incorporar, à gramática da decisão, alguma cogitação sobre consequências práticas. Aqui, a norma não gera controle da decisão, mas provoca a alteração do estilo da decisão" MENDONÇA, José Vicente Santos de. Dois futuros e meio para o projeto de lei de Carlos Ari. In: LEAL Fernando e MENDONÇA, José Vicente. Transformações do direito administrativo: Consequencialismo e estratégias. Rio de janeiro. Editora FGV, 2016, p. 33.

25 "A concepção particular que se propõe a defender as valorações de consequências enquanto elementos constitutivos da fundamentação de decisões judicantes, que de-vem, no entanto, ser inseridas e contempladas no âmbito dos processos decisórios com peso no máximo igual ao peso conferido a argumentos não consequencialistas, caracterizará então o tipo "fraco" de consequencialismo jurídico. "Definição especifica prevista no texto Consequencialismo Jurídico, Racionalidade Decisória e Malandragem. SCHUARTZ, 2008, p. 131.

${ }^{26}$ Para aprofundamento, vide: BAUMAN, Zygmunt. O mal-estar da pós-modernidade. Tradução Mauro Gama e Claudia Martinelli Gama. Rio de Janeiro: Jorge Zahar Ed., 1998a.

BAUMAN, Zygmunt. Modernidade e Ambivalência. Tradução Marcos Penchel. Rio de Janeiro: Jorge Zahar Ed., 1999.

BAUMAN, Zygmunt. Modernidade e Holocausto. Tradução Marcos Penchel. Rio de Janeiro: Jorge Zahar Ed, 1998 b.

${ }^{27}$ POSNER, Richard. Law, pragmatism and democracy. Cambridge: Harvard University press, 2003.

${ }^{28}$ MENDONÇA, 2014. p. 117.
} 


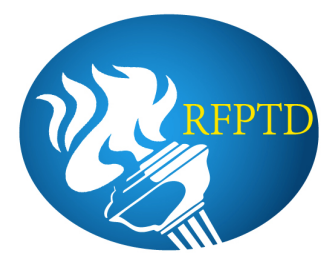

analisadas e escolhidas devem ser aquelas compatíveis com os princípios e valores constitucionais.

Apesar dessas limitações, o pragmatismo e o consequencialismo, este vem sendo usado cada vez mais atualmente ${ }^{29}$, visto, inclusive, por alguns autores como uma forma de pensamento adequada para caso que dependam de análise eminentemente prospectivas, como é o caso exemplificativamente das análises de impacto regulatório ${ }^{30}$. A mudança da técnica jurídica com a crescente utilização de princípios ao invés de regras ${ }^{31}$ também tem demandado análises consequencialistas, inclusive quando da utilização do postulado da proporcionalidade. Traçaremos agora um breve panorama do consequencialismo no direito tributário

\section{2)Pragmatismo e consequencialismo no direito tributário}

$\mathrm{O}$ direito tributário ${ }^{32}$ possui um caráter instrumental ${ }^{33}$ mais acentuado quando comparado a outros ramos do direito (ou seja, apesar de o direito ser distinto dos fins que propõe alcançar,

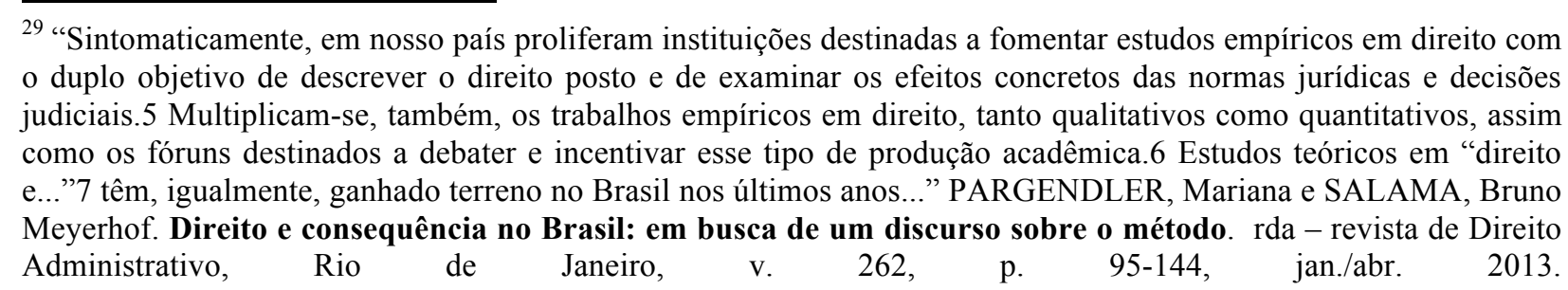
Administrativo, Rio de Janeiro, v. 262, p. 95-144, jan./abr.
$<$ http://bibliotecadigital.fgv.br/ojs/index.php/rda/article/view/8901/7809> acessado em> 07/04/2018. P. 97 .

${ }^{30}$ Kellner (2018, p 25), tratando da necessidade de retirar a constituição como referência para AIR seja constitucionalizada e, portanto, podendo ser analisada a partir de parâmetros mais voltada a ciência econômica, como a maximização da riqueza, defende: "A AIR pode ser objeto de uma aplicação teórica que sem referências a normas constitucionais almeja a aquisição de premissas normativas para uso em processos de aplicação do Direito. A desconstitucionalização da AIR parece fazer sentido, em razão da problemática axiológica de fixação de valores e determinação de sentido de normas infraconstitucionais por meio de normas constitucionais. A referida desconstitucionalização também parece fazer sentido em termos metodológicos, fato que decorre das dificuldades epistêmicas decorrentes da pluralidade de princípios, interesses e valores constitucionais e seus diferentes modos de aplicação, no caso ponderação ou subsunção..." KELLNER, Alexander Leonard Martins. A desconstitucionalização da análise de impacto regulatório como estratégia para sua implementação. In LEAL, Fernando e MENDONÇA, José Vicente Santos de. Transformações do Direito Administrativo: novas

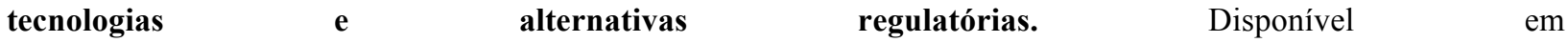
$<$ http://bibliotecadigital.fgv.br/dspace/handle/10438/18009>. Acesso em 8 de Abr. 2018. p. 25.

31 “O problema é que a correta aplicação de princípios mediante o teste de proporcionalidade depende, em muitos casos, e talvez na maioria deles, de dados empíricos ou pelo menos de juízos probabilísticos sobre os esperados efeitos concretos de diferentes normas." PARGENDLER, Mariana e SALAMA, Bruno Meyerhof. Direito e consequência no Brasil: em busca de um discurso sobre o método. rda - revista de Direito Administrativo, Rio $\begin{array}{llllll}\text { de Janeiro, } & \text { v. } & 262, & \text { p. } & 95-144, & \text { jan./abr. }\end{array}$ $<$ http://bibliotecadigital.fgv.br/ojs/index.php/rda/article/view/8901/7809><. P. 118 .

32 "Não há como desvincular a ideia de direito tributário da ideia de instrumento. Independentemente da natureza da norma tributária que se analise, sempre se terá como resultado que se trata de um instrumento para alguma finalidade: ou amealhar recursos para o Estado, ou induzir comportamentos considerados desejáveis para a consecução de finalidades estatais diversas da arrecadação.” ADAMY, Pedro. Instrumentalização do direito tributário. In. AVILA, Humberto. Fundamentos do Direito tributário. $1^{\text {a }}$ Edição. Editora Marcial pons. SP, 2012. P. 305 . 


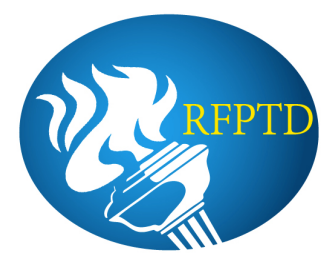

os meios (normas jurídicas), se colocados em funcionamento de forma adequada e intencional, são de alguma forma capazes de atingir finalidades especificas - ou seja, pode ser colocado como instrumento a serviço de uma teleologia estatal), fazendo surgir, ao nosso ver, a possibilidade da filosofia pragmática influenciar o direito tributário em função do foco quanto aos efeitos práticos obtidos. Aqui as decisões possuem fins e efeitos na esfera econômica e individual dos contribuintes e sobre o estado, especialmente as finanças públicas. Além disso, estes efeitos relacionam-se a direitos fundamentais dos contribuintes e do próprio estado, concretizando os princípios e valores constitucionais e legais ligados a este campo como a isonomia, justiça, segurança jurídica, entre outros (ainda que em algumas vezes encontram-se em lados opostos). ${ }^{34}$

Torres e Torres (2014, p. 118), ao tratar do consequencialismo no direito tributário, relata que “...o consequencialismo financeiro extrapolou-se recentemente da problemática da eficácia temporal do controle de constitucionalidade para o da eficácia prospectiva da alteração dos precedentes anteriormente firmados pelo $S T F . . ., 35$ complementando especificamente quanto a modulação temporal do efeito de decisões que “...a modulação dos efeitos da decisão judicial é fruto de pensamento consequencialista, seja favorável ao fisco, seja favorável ao contribuinte. É via de mão dupla. O argumento ad consequentiam passa a ter grande peso nas modernas teorias da justiça constitucional..." 36 . Nota-se o ganho de importância e a possibilidade de uso do consequencialismo no campo do direito tributário, ainda que hoje esteja mais voltado à questão da eficácia retroativa ou não quando da modulação de determinadas decisões judiciais.

Alguns estudos empíricos sobre modulações de decisões em direito tributário parecem não se preocupar muito com os possíveis efeitos a serem gerados, enfatizando a questão da segurança jurídica e legalidade como nortes para tomada de decisão: De Santi (2018) ao analisar possíveis efeitos da decisão do STF de modulação ou não no caso da retirada do ICMS da base de cálculo da Cofins para a União destaca:

\footnotetext{
33 "Certo é que outras instituições sociais podem - e de fato o fazem - buscar a consecução e o atingimento de objetivos e fins que também são finalidades almejadas pelo ordenamento jurídico. Tal fato, por si, não retira a legitimidade do direito como importante instrumento para a obtenção de fins” ADAMY, 2012. P. 303.

${ }^{34}$ Sobre o tema da constitucionalização do direito tributário, Lodi $(2009$, p.1) ensina: "Em uma outra dimensão, mais substancial, a constitucionalização do direito tributário se traduz na consolidação dos valores constitucionais como elementos legitimadores do ordenamento tributário, bem como no adequado manejo dos princípios constitucionais, notadamente os ligados à ideia de justiça, pelos tribunais e pela doutrina quando da aplicação da lei tributária..." - RIBEIRO, Ricardo Lodi. Temas de Direito Constitucional Tributário. Editora Lumien Iuris . SP. 2009 , p. 1.

${ }^{35}$ TORRES, Ricardo Lobo; TORRES, Silvia Faber. Estudos e pareceres de direito tributário. Ed. Elsevier. RJ. 2014, p. 118.

${ }^{36}$ TORRES e TORRES, 2014, p. 118.
}

Revista de Finanças Públicas, Tributação e Desenvolvimento - RFPTD, v. 6, n.6, 2018 


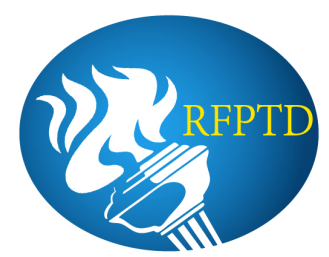

\begin{abstract}
"Pesquisa em casos positivos de modulação dos efeitos ex nunc revela que o posicionamento do STF é claro nesse sentido: a prospecção de efeitos é última opção, cabível apenas nas hipóteses de grave insegurança jurídica ou de violação de outro princípio da ordem constitucional que consubstancia excepcional interesse social...É descabido e juridicamente torpe admitir que o Fisco crie tributos em desrespeito à legalidade e à segurança jurídica mediante a edição de norma inconstitucional, para depois de reconhecida a patente inconstitucionalidade perante o STF, pleitear a convalidação dos efeitos de sua ilegalidade em nome da segurança jurídica. Portanto, é completamente descabida a pretensão do Fisco federal pleitear a modulação dos efeitos da decisão do STF que decretou a inconstitucionalidade da parte do artigo $7^{\circ}$, inciso I, da Lei 10.865, que se referia à inclusão do ICMS e do próprio PIS/COFINS-Importação na base de cálculo dessas contribuições: quem cria a insegurança não pode alegá-la em benefício próprio. Devendo os alegados R\$ 34 bilhões envolvidos na causa, servir tãoapenas na dosimetria da pena dos responsáveis por tamanho dano ao cidadão contribuinte., ${ }^{37}$
\end{abstract}

Em outras decisões de modulação de efeito em direito tributário pelo STF, observa-se, muitas das vezes, a ausência de estudos empíricos e dados sobre as prognoses feitas, o que também prejudica a aplicação do pensamento consequencialista no direito tributário, criando decisões casuísticas, mal fundamentadas, referindo-se às consequências de forma muito genérica. Dias e Leal (2017, p. 831) apontam em estudo sobreo uso de argumentos consequencialistas na jurisprudência do Supremo Tribunal Federal - STF para a modulação dos efeitos temporais da decisão declaratória de inconstitucionalidade em julgamentos de direito tributário "que em relação aos 25 casos em que houve a utilização de argumentos consequencialistas, somente em 5 fez-se referência a algum estudo, dado ou documento que pudesse embasar as prognoses feitas pelos ministros..."38. Os autores, diante deste e de outros argumentos previstos no artigo, entendem que o STF deve ser deferente aos dados empíricos da parte, ao menos se puder trazer elementos empíricos que efetivamente sejam melhores que os trazidos pela parte, sob pena de agir arbitrariamente:

\footnotetext{
"Se inexiste evidência demonstrando que os ministros têm capacidades epistêmicas melhores do que a de um indivíduo qualquer para atribuir probabilidades a eventos que podem ou não ocorrer no futuro então a adoção de uma postura deferente aos dados e estudos apresentados pelas partes, talvez, seja a mais adequada se o que se pretende é evitar o decisionismo arbitrário do intérprete.... 39 .
}

\footnotetext{
37 . DE SANTI, Eurico Marus Diniz. A modulação do controle de constitucionalidade de novos tributos. Disponível em < https://www.conjur.com.br/2014-jul-10/eurico-santi-modulacao-supremo-criacao-tributo\#author>a . Acesso em 09 de Abr. 2018.

${ }^{38}$ DIAS, Daniela Gueiros e LEAL, Fernando Angelo Ribeiro. Consequencialismo judicial na modulação de efeitos das decisões declaratórias de inconstitucionalidade nos julgamentos de direito tributário. Rev. Bras. Polít. Públicas, Brasília, v. 7, nº 3, 2017 Disponível em $<$ https://www.publicacoesacademicas.uniceub.br/RBPP/article/view/4779/3604>. Acesso em 8 de abr. 2018 . p. 839

${ }^{39}$ DIAS, LEAL, 2017, p. 839.
} 


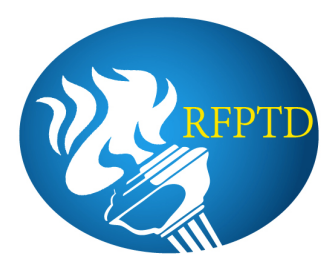

Assim, a decisão consequencialista implica na necessidade de estudos empíricos ${ }^{40} \mathrm{e}$ interdisciplinares, especialmente no direito tributário, dada a sua complexidade e a relação direta com outros campos do conhecimento.

No nosso caso de nosso estudo, a análise consequencialista terá por objetivo ver os efeitos da incidência da CIDE no domínio econômico do audiovisual, especialmente o segmento de mercado de VOD, tendo, portanto, natureza diferente das analises consequencialistas feitas em direito até hoje (focadas na decisão judicial que envolve modulação de efeitos nos termos do art. 27 da lei 9.868/1999). Buscaremos, assim, uma resposta sobre os efeitos da incidência no que se refere a parâmetros voltados para nossa ordem constitucional, de forma a verificarmos, efetivamente, se cumpre a Condecine Licença o seu papel finalístico de reduzir descompassos econômicos sobre o domínio em que incide.

\section{2-Segmento de mercado de VOD (Netflix)}

Antes de tratarmos, especificamente da CIDE Condecine, faremos uma brevíssima introdução sobre o segmento de mercado objeto de nosso estudo, o vídeo por demanda programado, o qual está inserido no mercado audiovisual, de forma a que, posteriormente, possamos fazer algumas relações sobre os efeitos da incidência da Condecine tendo em vista as características desse mercado e dos agentes que nele atuam.

O mercado audiovisual é caracterizado pela compra e venda de direitos sobre os filmes produzidos para exibição ${ }^{41}$, em negociações de caráter privado entre os entes da cadeia produtiva do setor (produtores, distribuidores e exibidores de conteúdo (tendo os programadores e radiodifusores como principais players "exibidores" de conteúdo no mercado de TV paga e aberta respectivamente)). O principal objetivo desse setor é a produção de

\footnotetext{
40، Nas regras jurídicas tradicionais, os fatos referidos no suporte fático estão no passado. Assim é no crime de homicídio, para apenas citar um exemplo simplório ("Art. 121. Matar alguém: Pena - reclusão, de seis a vinte anos"). Radicalmente diferente é a técnica utilizada na aplicação de princípios, na ponderação dos quais são necessariamente apreciados os efeitos futuros de um ou outro cenário para, então, optar-se pela incidência ou não da regra. Tanto assim que, ao pontuar as limitações do modelo de incidência ponteano à aplicação de princípios jurídicos, observaram os atualizadores do Tratado de direito privado que - diferentemente das regras, "normas imediatamente descritivas de comportamento" - "os princípios são normas imediatamente finalísticas, já que, ao invés de descreverem comportamentos, estabelecem um 'estado ideal de coisas' (isto é, um fim) cuja realização implica a adoção de determinados comportamentos.". Em outro trecho, os autores concluem: "É certo, porém, que semelhante técnica de decisão gera demanda por estudos científicos - teóricos, empíricos ou experimentais - nos moldes das demais ciências. " PARGENDLER e SALAMA, 2013. P. 123-124.

${ }^{41}$ Barros (2009) ensina que "[...] o business do mercado audiovisual é a compra e venda de direitos de adaptar, de distribuir, de reproduzir ou duplicar, de veicular, de exibir, etc. e só existe desta forma porque os países reconhecem a propriedade intelectual (Direitos de Autor ${ }^{41}$ )...". Vide - MARTINS, Vinícius Alves Portela. AGÊNCIA NACIONAL DO CINEMA - ANCINE: Comentários à Medida Provisória $\mathbf{N}^{\circ}$ 2.228-1/01, ao Decreto $\mathrm{N}^{\circ}$ 4.121/02 e à Lei No 12.485/11 - Vol. 24. Ed Atlas. SP, 2015.
}

Revista de Finanças Públicas, Tributação e Desenvolvimento - RFPTD, v. 6, n.6, 2018 


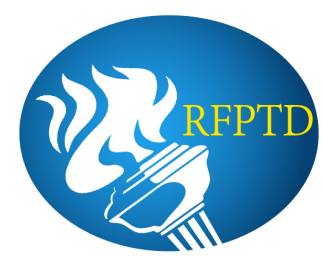

público/assinantes/audiência, o que é alcançado por meio da produção de conteúdo, filmes (meros meios para o alcance daqueles objetivos). O art. $1^{\mathrm{o}}$, VI da MP $2.228-1 / 2001^{42}$ traz os segmentos de mercado do setor audiovisual onde são explorados economicamente os conteúdos, sem previsão quanto ao segmento de vídeo por demanda; o mais próximo, dentre os que estão definidos legalmente, é o denominado vídeo doméstico ${ }^{43}$. Esses segmentos de mercado nada mais são que janelas de exploração comercial e exibição de conteúdos audiovisuais, as quais competem entre si, apontando para uma forte concorrência por público/audiência e renda nestas diferentes janelas, acirrando a competição especialmente em virtude da inovação tecnológica que frequentemente cria ou potencializa novas janelas, acirrando a competição entre as janelas tradicionais (cinema, TV aberta, paga, entre outros) e as mais novas como vídeo por demanda, uso de celulares para fruição de conteúdo audiovisual em qualidade cada vez melhor, etc.

Do ponto de vista econômico, é mercado que apresenta alto nível de concentração e barreiras à entrada na área de distribuição de conteúdo, especialmente em função das altíssimas economias de escalas $^{44}$ dada pela natureza do bem comercializado - conteúdo audiovisual, que possui um custo fixo altíssimo para sua produção e uma incerteza quanto à demanda do mesmo aumentando demasiadamente o risco econômico para atuação nesta atividade ${ }^{45}$. Por outro lado,

$42 \quad$ MP 2.228-1/2001 - Art. $1^{\circ}$ Para fins desta Medida Provisória entende-se como:

"VI - segmento de mercado: mercados de salas de exibição, vídeo doméstico em qualquer suporte, radiodifusão de sons e imagens, comunicação eletrônica de massa por assinatura, mercado publicitário audiovisual ou quaisquer outros mercados que veiculem obras cinematográficas e videofonográficas; BRASIL. Presidência da República. MP no 2.228-1 de 0609 2001. Estabelece princípios gerais da política nacional, do cinema, cria o conselho superior do cinema e a agência nacional do cinema - ancine, institui o programa de apoio ao desenvolvimento do cinema nacional - Prodecine, autoriza a criação de fundos de financiamento da indústria cinematográfica nacional Funcines, altera a legislação sobre a contribuição para o desenvolvimento da indústria cinematográfica nacional e dá outras providências. Brasília, DF., 2001 Disponível em: <www. planalto.gov.br>. Acesso em: 15 fev. 2016.

${ }^{43}$ Tecnicamente, pra fins de cobrança, na ausência de um segmento, cobra-se a partir do uso genérico da previsão contida em lei denominada outros mercados."

${ }^{44}$ Conceituando de forma bastante simplificada, a economia de escala traduz-se numa situação em que há aumento de produção com redução de custos, até uma determinada escala que é a chamada escala mínima eficiente. Ronaldo Fiani (2011, p. 47) no seu livro Cooperação e conflito cita: “...é característico do processo de desenvolvimento econômico gerar retornos crescentes de escala cuja presença é incoerente com o tipo de mercado competitivo; envolver externalidades positivas e negativas; demandar ofertas de bens públicos, ser confrontado com mercados incompletos. Esses são alguns dos aspectos que distanciam um mercado do seu ideal competitivo e que são conhecidos pela literatura como falhas de mercado...". A partir dessa citação, uma das falhas de mercado na literatura econômica - poder de mercado (que derivará numa estrutura de mercado oligopolista ou monopolista) - é essencial para o processo de desenvolvimento econômico, segundo o autor (junto inclusive com outras falhas citadas) a depender das características estáticas do mercado em questão. FIANI, Ronaldo. Cooperação e conflito. Instituições e desenvolvimento econômico. ${ }^{\mathrm{a}}$. Edição. Ed Elsevier. Rio de Janeiro, 2011. P. 47.

${ }^{45}$ Vide em - MARTINS, Vinícius Alves Portela. AGÊNCIA NACIONAL DO CINEMA - ANCINE: Comentários à Medida Provisória No 2.228-1/01, ao Decreto $N^{\circ}$ 4.121/02 e à Lei $N^{\circ}$ 12.485/11 - Vol. 24. Ed Atlas. SP, 2015. P. 100. 


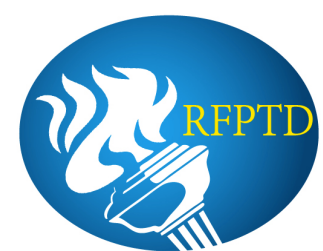

em especial pela característica de bem público ${ }^{46}$ em sentido econômico que tem o conteúdo audiovisual, temos que pelo lado do ofertante, o custo marginal para adicionar um novo consumidor seja próximo a zero, incentivando a oferta desse bem face a possibilidade de ganhos de escala altíssimos. (Ainda que, por outro lado, haja a possibilidade de comportamento de free rider por parte do demandante, ${ }^{47}$

A Instrução normativa 104/2012 da Agência Nacional do Cinema - Ancine define o segmento de vídeo por demanda como "prestação dos serviços de oferta de um conjunto de obras audiovisuais na forma de catálogo, com linha editorial própria, para fruição por difusão não-linear, em horário determinado pelo consumidor final, de forma onerosa",48. Quanto à forma de consumo pelo usuário, assemelha-se ${ }^{49}$ muito ao vídeo doméstico, pois o usuário escolhe ver os conteúdos que quiser, na hora que almejar, sendo a principal diferença o fato de no vídeo por demanda programada a pessoa poder fazer isto de casa, além de pagar por uma assinatura, enquanto que no vídeo doméstico paga-se por filme alugado, sendo necessário deslocamento desta até a locadora mais próxima. O segmento de vídeo doméstico é aquele complementar ao do cinema, onde são lançados os filmes que não chegam ao cinema ou aqueles em que a usam como $2^{\mathrm{a}}$ janela de lançamento (juntamente, hoje, com o payperview). O mercado de vídeo doméstico é

\footnotetext{
${ }^{46}$ Bens públicos são falhas de mercado assim como poder de mercado, externalidades e outros. Os bens públicos (em sentido econômico) são bens que possuem duas características que os diferenciam dos bens privados:

I) Não rivalidade - Implica que o custo marginal da produção do bem visando a servir um consumidor adicional é zero. Exemplo: uma autoestrada e audiência de uma rede de TV. Esses podem ser disponibilizados para todos, sem que seja retirada a oportunidade de consumo do bem ou serviço para terceiros;

II) Não exclusividade - Diz respeito ao fato de um bem ou serviço não poder ser excluído do consumo das pessoas. Exemplo: o ar puro propiciado por um programa de controle de poluição será consumido por todos.

No caso dos bens públicos econômicos, uma unidade a mais produzida não beneficia um, mas vários indivíduos na sociedade ao mesmo tempo, em função da sua não exclusividade. Considerando apenas o benefício marginal de um indivíduo, tal como faz o mecanismo de mercado, estaremos subestimando o benefício marginal social em virtude do fato que o consumo do bem ou serviço não se esgota nesses indivíduos, mas se estende para toda a sociedade.

${ }^{47}$ Para maiores informações sobre mercado audiovisual, vide MARTINS, Vinícius Alves Portela. AGÊNCIA NACIONAL DO CINEMA - ANCINE: Comentários à Medida Provisória $\mathbf{N}^{0}$ 2.228-1/01, ao Decreto $\mathrm{N}^{\circ}$ 4.121/02 e à Lei No 12.485/11 - Vol. 24. Ed Atlas. SP, 2015.

${ }^{48}$ Instrução Normativa da Ancine 104, 2009, art. $1^{\circ}$, L.

${ }^{49}$ Gabriel Stuckert $(2017$, p.13) defende, ao nosso ver com razão, que o VOD poderia tranquilamente estar classificado como vídeo doméstico, especialmente pelo fato de, na prática, o VOD apenas representar uma evolução tecnológica de algo que, na essência, é a mesma coisa. Nas palavras do autor: "A partir de conceitos de indústria cultural e indústria do audiovisual, procuramos aqui inserir o tema do Vídeo por Demanda (VOD) a partir de uma premissa bem simples, reiteradamente utilizada pelos seus próprios agentes de mercado: o VOD é apenas a atualização tecnológica do vídeo doméstico. Prosseguindo com esta premissa, vimos que questões como: a composição dos catálogos disponíveis, o espaço para o produto audiovisual brasileiro, a tributação dos produtos e deste serviço, especialmente em relação à CONDECINE, o monitoramento de informações relevantes deste segmento, além da eventual possibilidade de imposição de cotas de conteúdo poderiam encontrar respostas a partir da interpretação dos marcos legais já existentes." STUCKERT, Gabriel. VOD: o bom e velho mercado de vídeo doméstico. Revista GEMInIS, São Carlos, UFSCar, v. 8, n. 2, pp.04-15, mai. / ago. 2017. Disponível em $<$ http://www.revistageminis.ufscar.br/index.php/geminis/article/view/293/260>. Acesso 11 de Abr. 2018.
} 


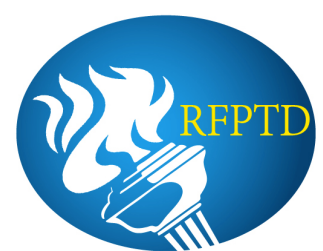

composto por duas subdivisões: o sell-thru, que representa as vendas feitas no varejo através dos hipermercados e o rental (aluguel dos filmes em vídeo locadoras para uso e posterior devolução).

Como dito, o VOD em muito se assemelha ao do vídeo doméstico ${ }^{50}$, especialmente do ponto de vista do demandante, dado que este frui conteúdo audiovisual na hora que achar conveniente, considerando a existência de um catálogo de filmes. A maior diferença, como dito, está na tecnologia que, em muito, facilita a vida do consumidor, sendo um ponto a favor dos agentes que atuam no segmento de vídeo por demanda, no âmbito da concorrência entre essas duas janelas. Mas a essência, a natureza da forma de consumir pautada na flexibilidade de conteúdo, flexibilidade de horário, etc. é semelhante de quando se está diante de uma vídeo locadora (segmento de vídeo doméstico) ou vídeo por demanda.

Entretanto, a tributação da Condecine Licença no âmbito desses dois segmentos se dá de forma diferente (considerando o que ocorre hoje): enquanto que no vídeo doméstico a distribuidora paga a CONDECINE por cada título (filme) em que possui o direito de distribuição, hoje, os agentes atuantes no segmento de vídeo por demanda não pagam a Condecine, ainda que incorram no fato gerador licenciamento ${ }^{51}$, responsável pela incidência da Condecine ${ }^{52}$. Agora, descreveremos a seguir características básicas da exação Condecine.

\section{A contribuição de intervenção no domínio econômico-CIDE Contribuição para o}

Desenvolvimento da Indústria Cinematográfica Nacional - Condecine (art. 32, II da MP

\subsection{8-1/2001)}

\footnotetext{
${ }^{50}$ Nunca é demais lembrar que o Netflix começou como um serviço de vídeo doméstico que levava em casa fitas de VHS, o que aponta para semelhança da natureza do vídeo doméstico para com o VOD - que apenas nos parece uma derivação em virtude de inovação tecnológica proveniente do primeiro. Vide em entrevista do próprio CEO da mesma, Reed hastings em - <https://veja.abril.com.br/revista-veja/a-qualidade-subiu/ $>$ Acesso em 16 de Mar de 2018.

${ }^{51}$ Há alguns posicionamentos, não acadêmicos, no sentido de que, quanto ao aspecto espacial do fato gerador da Condecine do art. 32, I, os licenciamentos não ocorreriam em território brasileiro. Acredito ser equivocada a tese, pois o serviço final é prestado no Brasil. Licencia-se para que um serviço seja prestado regularmente em território brasileiro. Hoje, temos a incidência do ISS sobre esse serviço, agora em consonância com o princípio da legalidade estrita tendo em vista as alterações da lei complementar 157 de 2016. Esta consideração parece apontar para o fato de que o próprio licenciamento ocorra, de fato, no Brasil, ainda que haja mecanismos meramente formais/contratuais que coloquem em xeque a ocorrência desse fato gerador em território brasileiro.

${ }^{52} \mathrm{O}$ art. 32 traz como fato gerador da Condecine Licença a distribuição, veiculação, produção e licenciamento de obras audiovisuais. Existe uma discussão sobre a incidência da Condecine prevista no art. 32, I quanto a incidência monofásica dessa exação. Isso porque o termo usado na redação é o "será devido uma única vez" e não incidirá uma única vez, tal como previsto no art. 149 da CF ao tratar da possibilidade de incidência monofásica em CIDE. Diante disso, existe a possibilidade de que o termo "será devido uma única vez" faça referência a ocorrência, no caso em concreto, a realização de cada um dos fatos geradores previstos no art. 32, I, quando for o caso, o que poderia triplicar a incidência. Mas no caso da incidência do videodoméstico não há esse problema, dado que o único FG que ocorre é o do licenciamento. E o mesmo vale para o vídeo por demanda programado. Vide - MARTINS, V.A.P “A questão da (in)definição sobre incidência monofásica no caso de contribuições de intervenção no domínio econômico-CIDEs: o caso da Condecine” publicado na Revista dos tribunais No 98, 2011.
} 


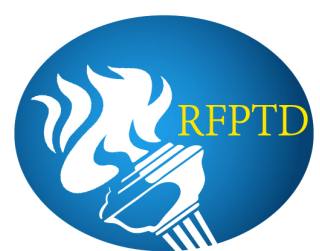

A Condecine é a CIDE $^{53}$ incidente sobre o setor cinematográfico/audiovisual. Sendo uma

CIDE, segue as características básicas principais que marcam esse tributo como a destinação da receita $^{5455}$ a um fim específico, previsto legalmente. A intervenção pode ser caraterizada tanto pela incidência ${ }^{56}$ por si do tributo, como também pela aplicação da receita da exação no âmbito deste domínio econômico. Ademais, vale destacar que um dos principais objetivos ${ }^{57}$ da CIDE é concretizar os princípios da seara econômica previstos no art. $170^{58}$, tendo também a referibilidade $^{59}$ como princípio, no sentido aplicado a esta espécie. ${ }^{60}$

\footnotetext{
${ }^{53}$ CIDE é uma espécie de contribuição (que é espécie de tributo) prevista na Carta Magna em seu art. 149.

${ }^{54}$ Tácio Lacerda Gama (2003 p.130) que cita que "...o critério que permite identificar as contribuições interventivas, separando-as das demais espécies, é a finalidade especial prescrita para o produto de sua arrecadação." GAMA, Tácio Lacerda. Contribuições de Intervenção no Domínio Econômico. Ed Quartier Latin. São Paulo, 2003. p. 130.

${ }^{55} \mathrm{Com}$ relação à jurisprudência e no que tange à constitucionalidade dessa exação, o STF tem posicionamento pacífico no sentido de que são constitucionais, pois que representam um instrumento de intervenção, tendo como condição fundamental a aplicação das receitas desta na finalidade para a qual foi criada - vide RE 396.266/SC, Rel. Min. Carlos Velloso; RE 389.016-AgR/SC, Rel. Min. Sepúlveda Pertence; RE 389.020-AgR/PR; Rel. Min. Joaquim Barbosa, entre outros etc.

${ }^{56}$ Paulsen (2009 p. 125) afirma que "pode-se vislumbrar contribuição que, pela sua própria cobrança, implique determinado efeito, configurando em tal caso ela própria a pretendida intervenção..." PAULSEN. Leandro. Direito tributário: constituição e código tributário a luz da doutrina e da jurisprudência. Ed livraria dos advogados. Porto Alegre. 2009, p. 129.

Sobre o mesmo assunto, vide também MARTINS, Vinícius Alves Portela. Possibilidades de intervenção regulatória por parte de CIDEs: o caso especifico da Condecine

$<$.http://www.seae.fazenda.gov.br/premio-seae/edicoes-anteriores/edicao-2009/iv-premio-seae-2009> . Brasília. IV Prêmio SEAE, 2009. Como muitos autores atribuem a essa incidência uma característica de extrafiscalidade da CIDE, Marco Aurélio Greco aponta que não faz sentido falar em extrafiscalidade, atribuindo essa característica às contribuições interventivas, mas sim imposto, pois o mesmo tem função fiscal. Segundo o autor, a arrecadação de receita da CIDE não é parâmetro para aferir significado e função de exigência da exação, apontando para o fato de que tributos existem por causa de sua finalidade e não em função do que arrecadam ou não. Greco Descreve que "...ainda que se pretendesse aplicar o conceito de extrafiscalidade às contribuições, forçoso seria reconhecer...que, em relação a elas, a extrafiscalidade poderia assumir uma função positiva e não negativa.." GRECO, Marco Aurélio. Contribuição de intervenção no domínio econômico e figuras afins. Ed. Dialética, 2001. p. 25-26.

57 "Se nos tributos que objetivam a arrecadação de recursos para o Estado deve-se analisar a igualdade na distribuição total da carga fiscal bem como a capacidade contributiva de cada contribuinte, nos tributos com finalidades extrafiscais a análise deve recair nos direitos fundamentais restringidos pela norma indutora e sua relação com as finalidades estatais pretendidas. O tributo, portanto, entendido como divisão social dos custos estatais e de financiamento dos serviços e bens públicos perde em intensidade, sendo instrumentalizado para o atingimento de finalidades estatais diversas. Pode-se dizer que há um relativo abandono dos critérios da igualdade e capacidade contributiva em favor de outras finalidades julgadas relevantes.39 Em tributos que têm natureza instrumental, isto é, buscam atingir finalidades político-econômicas diversas da arrecadação, a igualdade e a capacidade contributiva tem eficácia normativa relativa". Este é exatamente o caso da CIDE. Deve estar antenado, na medida do possível, aos valores que remetem a tributação com fim fiscal como a igualdade; mas também deverá estar relacionada ao atingimento de outros valores e princípios desligados da seara tributária; e, na maior parte das vezes, estes deverão ter maior peso. ADAMY, Pedro. 2018 p. 313

${ }^{58}$ Miguez Mello (2002 p. 186) ${ }^{58}$ afirma: "neste particular merece ser posto em relevo que a Lei Maior consagrou diversas finalidades econômicas em seu artigo 170. A CIDE deverá favorecer, jamais poderá contrariar as finalidades econômicas visadas pelo artigo 170 da Carta Política..." MELLO. Gustavo Miguez. Contribuições de Intervenção no Domínio Econômico: in pesquisas tributárias série 8. São Paulo: RT, 2002. P. 186.

${ }^{59}$ Hoffman (1997, p. 347), nesse sentido, descreve que: "o legislador costuma indicar como sujeito passivo pessoas alheias ao fato descrito no critério material da hipótese jurídica, o que, no caso específico das contribuições, resulta
} 


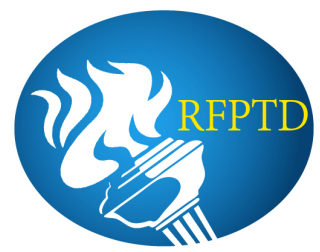

A Condecine Licença (art. 32, II da MP 2.228-1/2001) $)^{61}$, tem como fatos geradores (aspecto material da incidência ${ }^{62}$ ) veiculação, a produção, o licenciamento e a distribuição de obras cinematográficas e videofonográficas com fins comerciais, por segmento de mercado a que forem destinadas. Com relação ao aspecto temporal de sua incidência, essa será devida uma única vez ${ }^{63}$ a cada cinco anos para cada segmento de mercado por título ou capítulo de obra cinematográfica ou videofonográfica destinada aos seguintes segmentos: salas de exibição (cinema); vídeo doméstico, em qualquer suporte; serviço de radiodifusão de sons e imagens (TV aberta); comunicação audiovisual de acesso condicionado e outros mercados ${ }^{64}$. O tributo deverá ser recolhido, de uma forma geral, na data do registro do título ou até o primeiro dia útil seguinte ou na data da concessão do certificado de classificação indicativa, a depender do normatizado em

na sua descaracterização, pois nesse tributo há, necessariamente, um vínculo entre quem paga e o fato descrito no critério material da hipótese tributária..."

${ }^{60}$ As taxas e contribuições de melhoria tem fundamento no princípio do custo benefício e da referibilidade (devese cobrar apenas do grupo relacionado àquele setor em que se quer tributar), a qual pode ser individual (aplicada as taxas e contribuições de melhoria - contraprestação estatal direta) ou de grupo (ligado às contribuições parafiscal). Lodi (2010, p. 115) acrescenta que é preciso considerar que "o aspecto finalístico de seu fato gerador... deve estar coadunada com os demais aspectos deste, especialmente os nucleares (fato gerador em sentido estrito), pessoais (contribuinte) e quantitativos (especialmente a base de cálculo). Essa adequação entre finalidade e os demais aspectos do fato gerador é denominada de referibilidade de grupo... cuja a destinação deve ser atividade estatal que...se relacione com o grupo que participa." RIBEIRO. Ricardo Lodi. As contribuições parafiscais e a validação constitucional das espécies tributárias. São Paulo. Revista dialética de direito tributário. VOL. 174, 2015. P.128

${ }^{61}$ Trataremos somente da Condecine Licença, espécie prevista no art. 32, I da MP 2.228-1/2001, não tratando da Condecine Telecom (art. 32, II) e Condecine Rendimento (parágrafo único do art. 32). Para maiores informações sobre Condecine, vide: MARTINS, V.A.P. A contribuição para o desenvolvimento da indústria cinematográfica - Condecine: uma contribuição sui generis?. Revista Tributária e de Finanças Públicas, v. 110, p. 279-303, 2013.

62 Segundo Ataliba (1991 p. 73-75) “[...]a hipótese de incidência é a descrição legislativa (necessariamente hipotética) de um fato cuja ocorrência in concreto a lei atribuiu força jurídica de determinar o nascimento da obrigação tributária...esta categoria ou protótipo (hipótese de incidência) se apresenta sob variados aspectos, cuja reunião lhe dá entidade. Tais aspectos não vêm necessariamente arrolados de forma explícita e integrada na lei...são, pois, aspectos da hipótese de incidência as qualidades que esta tem de determinar hipoteticamente os sujeitos das obrigações tributárias, bem como seu conteúdo substancial, local e momento de nascimento. Daí designarmos os aspectos essenciais da hipótese de incidência tributária por: aspecto pessoal, aspecto material; aspecto temporal e aspecto espacial." ATALIBA, Geraldo. Hipótese de incidência tributária., 4ª edição, RT, 1991, p. 73 e 75. Vide também sobre estruturalismo e linguística em direito tributário, especialmente quanto a regra matriz de incidência tributária o autor Paulo Barros de Carvalho - Curso de direito tributário 27a. Ed. Saraiva, 2016 ou Breves considerações sobre a função descritiva da Ciência do Direito Tributário

$<\quad$ https://www.conjur.com.br/2013-out-01/paulo-barros-breves-consideracoes-funcao-descritiva-ciencia-direitotributario $>$.

${ }^{63}$ A questão da incidência única da Condecine - incidência monofásica - é tratada com maior profundidade em MARTINS, V.A.P “A questão da (in)definição sobre incidência monofásica no caso de contribuições de intervenção no domínio econômico-CIDEs: o caso da Condecine” publicado na Revista dos tribunais $\mathrm{N}^{\circ} 98$, 2011.

${ }^{64}$ MP 2.228-1/2011 - “ Art $1^{\text {o }}$ VI - segmento de mercado: mercados de salas de exibição, vídeo doméstico em qualquer suporte, radiodifusão de sons e imagens, comunicação eletrônica de massa por assinatura, mercado publicitário audiovisual ou quaisquer outros mercados que veiculem obras cinematográficas e videofonográficas...”; Cabe ressalvar que com a aprovação do PLC 116 em lei, o segmento de comunicação eletrônica de massa por assinatura passa a ser denominado de comunicação audiovisual de acesso condicionado.

Revista de Finanças Públicas, Tributação e Desenvolvimento - RFPTD, v. 6, n.6, 2018 


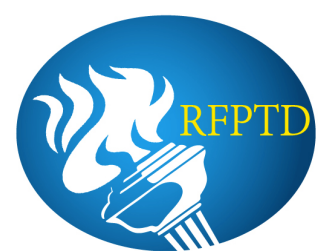

regulamento infra-legal e do segmento de mercado em questão ${ }^{65}$. No que tange ao aspecto pessoal do fato gerador da referida exação, o sujeito ativo para a cobrança desta é a União, por intermédio da Ancine. Já o sujeito passivo será o detentor do direito de comercialização, no caso de obra não-publicitária. Quanto ao aspecto quantitativo de seu fato gerador, a Condecine Licença utiliza a denominação de alíquota específica ${ }^{66}$, possuindo valores fixos que variam de acordo com a classificação da obra, sua nacionalidade e finalidade (publicitária ou não publicitária). Quanto ao aspecto espacial, só incide sobre obras exibidas/licenciadas/distribuídas em território brasileiro. Por fim, temos que o produto da arrecadação da Condecine (Licença e/ou Rendimento) será destinado ao Fundo Nacional da Cultura - FNC e alocado em categoria de programação específica denominada Fundo Setorial do Audiovisual-FSA ${ }^{67}$, para aplicação nas atividades de fomento relativas aos Programas de que trata o art. $47^{68}$ da MP 2.228-1/2001.

Apesar do objetivo principal aqui ser arrecadar recursos para intervenção da União, isso não significa que sua incidência e a consequente intervenção dela derivada não surta efeitos sobre o mercado audiovisual e os diferentes segmentos no qual incide. Na verdade, a tributação é vista por alguns autores como instrumento ${ }^{69}$ e meio de se atingir um fim, devendo, no entanto, ser restringido em respeito aos direitos fundamentais. A análise dos efeitos do uso desse instrumento, então, deve ser feita em respeito aos princípios e valores previstos no ordenamento

\footnotetext{
${ }^{65}$ No caso da Condecine Rendimento - parágrafo único do art. 32 da MP 2.228-1/2001 - essa deverá ser recolhida na data do pagamento, crédito, emprego ou remessa das importâncias referidas no parágrafo único do art. 32.

${ }^{66} \mathrm{CF} / 1988$ “...Art. 149. Compete exclusivamente à União instituir contribuições sociais, de intervenção no domínio econômico e de interesse das categorias profissionais ou econômicas, como instrumento de sua atuação nas respectivas áreas, observado o disposto nos arts. 146, III, e 150, I e III, e sem prejuízo do previsto no art. 195 , $\S 6^{\circ}$, relativamente às contribuições a que alude o dispositivo....

...§ $2^{\circ}$ As contribuições sociais e de intervenção no domínio econômico de que trata o caput deste artigo: (Incluído pela Emenda Constitucional no 33 , de 2001)...

III - poderão ter alíquotas: (Incluído pela Emenda Constitucional n 33, de 2001)

a) ad valorem, tendo por base o faturamento, a receita bruta ou o valor da operação e, no caso de importação, o valor aduaneiro; (Incluído pela Emenda Constitucional no 33, de 2001)

b) específica, tendo por base a unidade de medida adotada. (Incluído pela Emenda Constitucional n ${ }^{\circ} 33$, de 2001)..." BRASIL. Presidência da República. Constituição Federal. Disponível em: http://www.planalto.gov.br/ccivil_03/constituicao/constituicao.htm_Acesso em: 12 dez. 2010.

${ }^{67}$ Lei $11.437 / 2006$ - “...Art. $1^{\circ}$ O total dos recursos da Contribuição para o Desenvolvimento da Indústria Cinematográfica Nacional - CONDECINE, criada pela Medida Provisória no 2.228-1, de 6 de setembro de 2001, será destinado ao Fundo Nacional da Cultura - FNC, criado pela Lei no 7.505, de 2 de julho de 1986, restabelecido pela Lei no 8.313, de 23 de dezembro de 1991, o qual será alocado em categoria de programação específica, denominada Fundo Setorial do Audiovisual, e utilizado no financiamento de programas e projetos voltados para o desenvolvimento das atividades audiovisuais

${ }^{68}$ Prodecine, Prodav e Proinfra. Maiores informações ver link http://www.ancine.gov.br/fsa/.

69 "Não há como desvincular a ideia de direito tributário da ideia de instrumento. Independentemente da natureza da norma tributária que se analise, sempre se terá como resultado que se trata de um instrumento para alguma finalidade: ou amealhar recursos para o Estado, ou induzir comportamentos considerados desejáveis para a consecução de finalidades estatais diversas da arrecadação. Em suma: «o direito tributário não tem objetivo próprio»,15 ele atua como instrumento para a consecução de outros objetivos. ADAMY, 2018, p. 305.
}

Revista de Finanças Públicas, Tributação e Desenvolvimento - RFPTD, v. 6, n.6, 2018 


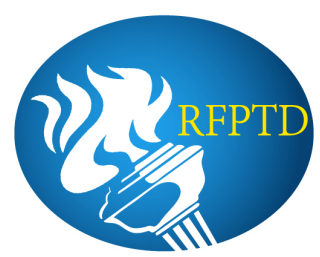

jurídico, (retornando a estes) ${ }^{70}$. E é sobre esse ponto que nos tratando da análise dos efeitos da incidência desta sobre o segmento de VOD.

\title{
4. A problemática da incidência e da não incidência da Condecine Licença tendo em vista as consequências geradas pela mesma no segmento de vídeo por demanda
}

\subsection{Considerações quanto ao uso do método consequencialista na análise da incidência e}

\section{não incidência da Condecine Licença (art. 32, I da MP 2.228-1/2001)}

A análise consequencialista, descreverá as possíveis consequências, tomando-as como critério e parâmetro para tomada de decisões. Entretanto, cabe ressaltar que a escolha por critérios pragmáticos também possui seus problemas. Um deles é a falta de segurança quanto a escolha dos possíveis melhores efeitos para uma dada decisão; seu rankeamento em ordem de importância, em torno de critérios claros e objetivos que auxiliem, de fato, a escolha da decisão mais adequada ao caso concreto. Nesse sentido, Leal (2017, p. 28) ensina que:

\begin{abstract}
“ trabalhar com consequências em processo de tomada de decisão jurídica envolve dois tipos distintos de incerteza. O primeiro se localiza na dimensão positiva ou descritiva, como controlar essas prognoses? Como torná-las confiáveis e não produto de especulações intuitivas sobre o futuro? O segundo tipo de incerteza diz respeito à dimensão normativa do raciocínio. Uma vez identificadas as consequências vinculadas a cada alternativa decisória, o tomador de decisão deve indicar um critério com base no qual ordenará as consequências para, só então, justificar a sua preferência por determinado curso de ação...não estando claro o critério de valoração, o problema é que o tomador de decisão segue livre para ranquear as consequências a sua maneira...”, „11
\end{abstract}

Assim, o grau de subjetivismo decisional pode mudar de nome, adotando-se um consequencialismo que não enseje numa decisão mais racional, mas uma escolha aleatória por uma dada consequência (sem estar associada a um critério de valoração relacionado com o caso concreto) que leve a decisão que o tomador deseja, sem domesticar, assim, as incertezas deste processo que hoje observamos, através do uso inconsequente da teoria dos princípios, etc. O mesmo autor (2017, p.28), em outro trabalho, aponta outro problema, qual seja, o acréscimo de mais um elemento argumentativo que não leve, necessariamente, ao aumento da qualidade da

\footnotetext{
70 “A utilização do direito tributário como meio para o atingimento de finalidades pode, por vezes, entrar em colisão direta com os direitos fundamentais. Assim como nas demais esferas do direito, os direitos fundamentais atuam de forma transversal no direito tributário, isto é, atravessam-no por completo, influenciando a criação, conformação e interpretação dos institutos jurídico tributários. Na tributação dirigida a finalidades não é diferente, permanecendo ela sendo «regida pela generalidade dos princípios constitucionais dosistema».38 Aqui, no entanto, há um enfraquecimento - não sua extinção ou sua negação - de alguns dos princípios informadores da tributação, uma vez que entram em cena outros objetivos da ordem constitucional, que não a finalidade arrecadatória de meios financeiros para o Estado" ADAMY, 2018 p. 312.

${ }^{71}$ LEAL, Fernando Angelo Ribeiro. Considerar as consequências das decisões resolve? Uma análise crítica do PL 349/15. <http://www.direitodoestado.com.br/colunistas/fernando-leal/considerar-as-consequencias-das-decisoesresolve-uma-analise-critica-do-pl-34915> Acesso em 2 de fev. 2017. Vide também - ARGUELHES, Diego Werneck e LEAL, Fernando. Pragmatismo como [Meta]Teoria da Decisão Judicial: Caracterização, Estratégias e Implicações. In: Daniel Sarmento (Org.). Filosofia e Teoria Constitucional Contemporânea. Rio de Janeiro: Lumen Juris, 2009, p. 190.
} 


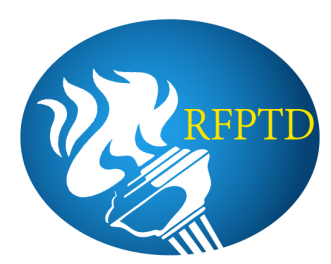

justificação em si, podendo, inclusive, aumentar o nível de incerteza quanto a tomada de decisão. Nas palavras do autor, comentando o novo art. 26 da lei de introdução a normas do direito brasileiro (PL 349/2015 que propõe a inserção da consideração de consequências em tomadas de decisão) cita:

"O problema é que do aumento quantitativo de referências de argumentação não se infere o aumento da qualidade da justificação. Nesse aspecto, apenas ao exigir a consideração de consequências sem estabelecer critérios para neutralizar certas dificuldades intrinsecamente relacionadas ao trabalho com efeitos de alternativas de decisão, o projeto de lei pode não ser capaz de reduzir as incertezas de processos decisórios que se sustentem sobre princípios vagos ou que invalidem os atos referidos no artigo 26 que se pretende incluir na Lei de Introdução. Ao contrário. Assim como do aumento quantitativo dos referenciais de argumentação os autores do projeto de lei parecem assumir o aumento da qualidade da justificação, é igualmente possível sustentar que esse aumento quantitativo, nos termos do projeto de lei, poderá aumentar os níveis de incerteza nos processos de tomada de decisão jurídica..., ${ }^{72}$

No direito tributário, o uso de prognoses sem fundamentação empírica adequada (modulação de efeitos das decisões de inconstitucionalidade com base no art. 27da lei 9.868/1999) tem se mostrado problemático, o que aponta para a necessidade de uma postura cautelosa no uso de argumento consequencialista neste campo. Quanto a esta questão, Leal (2017, p.839) ensina que:

\begin{abstract}
“...a argumentação consequencialista realizada pelos ministros do Supremo Tribunal Federal para modular os efeitos da declaração de inconstitucionalidade em julgamentos de direito tributário pode ser considerada problemática por duas razões distintas A primeira delas é relativa a uma limitação necessária da argumentação preocupada com os efeitos práticos da decisão. Ela diz respeito à incerteza inerente à atribuição de consequências para cada alternativa decisória e à limitação racional dos ministros para trabalharem com diversas variáveis bem como analisarem provas complexas. A segunda limitação é contingente e é evidenciada pelos dados empíricos coletados. Trata-se do fato de que os juízos de prognose realizados pelos ministros não são acompanhados de estudos que demonstrem a sua ocorrência. Essas duas limitações, talvez, indiquem que a melhor postura a ser adotada pelos ministros é, em relação às provas e estudos apresentados pela parte, uma de deferência, enquanto, em relação à sua própria argumentação, uma que procure evitar o uso de consequências não demonstradas ao longo do processo",73
\end{abstract}

Assim, seja pela limitação racional no uso dessa argumentação, seja pela complexidade para obtenção de provas que permitam juízo pragmáticos mais embasados seguros, seja pela ausência de estudos empíricos que fundamentem determinadas decisões consequencialistas, o uso desse tipo de argumentação deve ser feito de forma criteriosa, de forma a evitar verdadeiras mentiras argumentativas, como apontado no estudo por parte do ministro Gilmar Mendes! ${ }^{74}$ Por outro

\footnotetext{
${ }^{72}$ LEAL, Fernando Angelo Ribeiro. Inclinações pragmáticas no direito administrativo: nova agenda, novos problemas. O caso do PL 349/15. In: LEAL Fernando e MENDONÇA, José Vicente. Transformações do direito administrativo: Consequencialismo e estratégias. Rio de janeiro. Editora FGV, 2016, p. 28.

${ }^{73}$ DIAS, e LEAL, 2017. p. 839

${ }^{74}$ No voto do 405579 , onde se discutia teve que decidir se o benefício de $40 \%$ de redução de alí- quota do Imposto de Importação, concedido a empresas montadoras e fabricantes de veículos, poderia ser estendido, com base na
} 


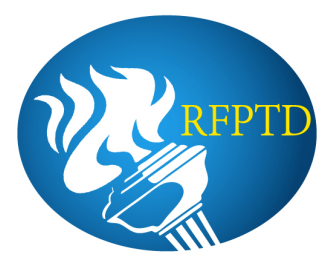

lado, argumentações de cunho ideológico que deem sobrepeso (a priori) a questão da segurança jurídica e da legalidade independentemente do contexto analisado também não devem prosperar, pois ignora elemento essencial do pensamento pragmático: a contextualização e a busca por dados empíricos. Cada contexto deve ser analisado como um todo para obtenção da melhor decisão possível, sem que ideologias pré-concebidas seja o fim a ser atingido.

O parâmetro de nossa analise consequencialista buscará na escolha e seleção das consequências, na medida do possível, àquelas que conduzam a melhor concretização de princípios (seguiremos os standards de aplicação do "principio" do pragmatismo jurídico sugerido por Mendonça (2014, p. 442-443), especificamente quanto a considerar consequências que possam ser reconduzidas materialmente à constituição ${ }^{75}$ ). Aproxima-se, assim, do denominado consequencialismo malandro ${ }^{76}$ Schuartz (2008, p. 157), que busca aliar o consequencialismo à dogmática jurídica, avançando sobre entendimentos passados, mas sem rompê-los de forma definitiva com a dogmática, a produção teórica passada, fazendo uma espécie de transição e aproveitando o melhor do antigo e do novo:

“as novas sacadas e as soluções inovadoras devem agregar-se ao estoque prévio de doutrina se decisões de maneira a produzir o menor distúrbio possível. Como apontado na parte final da Seção 2, entretanto, a deferência aos entendimentos e precedentes vindos do passado está, no pragmatismo jurídico, a serviço da e condicionada pela concepção particular do decisor sobre a contribuição dessa deferência ao bem comum. O pressuposto da malandragem, por sua vez, é que, no direito, o governo do presente deve caber ao passado e não ao futuro. Ao invés de ser concessão do decisor, a deferência agora é uma condicionante do processo de fundamentação da decisão. Assim é que, na inovação malandra, não há celebração de descontinuidade de fissuras heroicamente produzidas, mas, ao contrário, preocupação em religar, sem alardes, a conexão com a ordem que se desfez...."77 .

isonomia, a uma empresa que, embora importasse pneus, não os produzia, o ministro Gilmar Mendes usou bases empíricas desconexas com o tema em questão, buscando, neste caso, um argumento de autoridade não relacionado diretamente ao tema em questão, apesar de forma distante, ter relação com tema, dado que tratou da questão de equilíbrio de mercado e concorrência perfeita. Nas palavras de Leal (2017, p. 836): "Antes de se avançar no argumento, é pertinente destacar que citação do manual de análise econômica de Cooter e Ulen no voto de Gilmar Mendes não apresenta nenhuma relação direta com o tema objeto de discussão no julgamento. As páginas citadas tratam, genericamente, do equilíbrio do mercado, abordando questões que vão desde o equilíbrio em indústrias perfeitamente competitivas até o equilíbrio em mercados monopolísticos e a capacidade de imposição de preço nesses últimos."

DIAS, e LEAL, 2017. p. 836.

${ }^{75}$ Mendonça $(2014$, p.68): “ ...apresentamos oito Standards destinados a guiar a incidência de nosso princípio do pragmatismo. São eles: [...] (4) considera apenas consequências que possam ser reconduzidas materialmente à Constituição...”. MENDONÇA, 2014, P. 68.

${ }^{76}$ Não adotaremos, aqui, um modelo de consequencialismo forte, nos moldes do citado por Kellner (2018, p.11): "Um consequencialismo forte se exterioriza por meio da supremacia de um critério valorativo de consequências em relação a eventuais critérios de correção considerados relevantes. ” KELLNER, 2018, p. 11.

${ }^{77}$ SCHUARTZ, 2008, p. 157. 


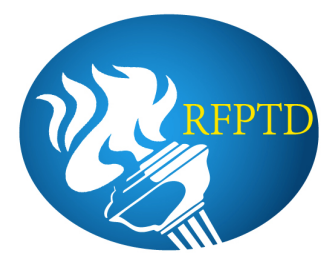

Assim, procuraremos descrever consequências econômicas próximas e prováveis, derivadas da intervenção ocasionada pela incidência e não incidência da Condecine, relacionando aos princípios do art. 170 e tributários afetos.

\subsection{A análise consequencialista da incidência da Condecine Licença (art. 32, I da MP 2.228-}

\section{1/2001) sobre segmento de VOD}

Nossa analise consequencialista será composta de quatro etapas: 1- Identificação das decisões possíveis (incidência ou não incidência de Condecine sobre VOD); 2- Localização de suas consequências; 3- Ranqueamento dessas consequências; 4- Indicação, diante dessas análises, da consequência (ou medida) que melhor concretiza valores e princípios ligados à instituição de CIDEs e da Condecine, considerando características básicas deste mercado e a estrutura do tributo Condecine. Veja que o critério de ordenação das consequências será aquele que concretizará com maior eficácia os princípios do art. 170 da CRFB além de outros ligados à tributação.

Com relação a etapa 1 , a decisão pode se dar a favor ou contra a incidência da Condecine no segmento de VOD.

Quanto a etapa 2, há de se analisar as consequências possíveis em caso de incidência ou não incidência da Condecine Licença sobre VOD.

Havendo incidência, uma consequência bastante provável para as empresas atuantes no segmento de VOD seria o aumento do custo (o que a princípio ocorre sempre que é criado um tributo). Analisando os prováveis efeitos econômicos nos agentes atuantes neste segmento, de acordo com a teoria microeconômica neoclássica tradicional ${ }^{7879}$, este aumento de custo poderia ser internalizado pela empresa, o que tornaria este mercado menos atraente a novos ofertantes, pois haveria fatalmente uma diminuição de sua margem de ganho. Outra consequência possível seria o aumento das barreiras a entrada tendo em vista o aumento do custo fixo inicial para operação no setor. Além disso, uma menor quantidade de ofertantes (em virtude da margem de ganhos menores) significaria, pelo menos a princípio, menor probabilidade de concorrência neste

\footnotetext{
${ }^{78}$ Para aprofundamento, vide: KRUGMAN, Paul; e WEELS, Robin. Microeconomia uma abordagem moderna. 3a. Edição. São Paulo. Editora Elsevier, 2014. Vide também O livro "Law \& Economics" de Robert Cooter e Thomas Ulen ou ainda MARTINS, V.A.P. Regulação e defesa da concorrência. $1^{\mathrm{a}}$. Edição. Rio de janeiro. Ed Forense, 2014.

${ }^{79}$ Mesmo que fossem utilizados outros parâmetros de analise, inclusive mais modernos, ligados a concorrência, como a schumpteriana (Joseph Schumpeter), que critica a análise econômica e concorrencial da teoria microeconômica neoclássica, apresentando a teoria dinâmica da concorrência e os conceitos de progresso técnico, destruição criadora, monopólio temporário, entre outros, não vemos como estas pudessem extrair uma posição da intervenção feita pela Condecine que levasse a uma melhor concretização dos princípios ligados a esta. Para maiores informações sobre o tema desta nota, vide - SCHUMPETER, Joseph A. Capitalismo, Socialismo e Democracia. $1^{\mathrm{a}}$. Edição. Rio de Janeiro: ZAHAR Editores, 1984.
} 


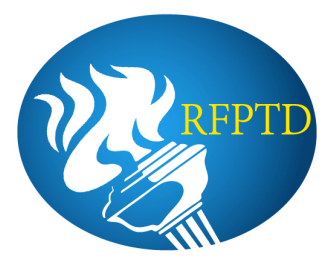

segmento. Caso a empresa de VOD repasse este custo ao consumidor, haveria um aumento do preço do serviço, levando, pela teoria geral do equilíbrio em economia - lei da oferta e da demanda - a uma diminuição em sua demanda, reduzindo novamente a margem da empresa. $\mathrm{Ou}$ um prejuízo ao consumidor em face do valor maior a ser cobrado dele, diminuindo o bem-estar do mesmo.

Observe o exemplo de forma a que se verifique o impacto no ofertante em números: a incidência do valor de Condecine Licença, considerando o aspecto quantitativo de seu fato gerador, se dá por cada título licenciado pelo distribuidor à empresa de VOD. Considerando que essas empresas adquiram, para fins de disponibilização ao usuário, milhares de títulos (e neste modelo, na verdade, quantos mais títulos, melhor para o consumidor), poderia inviabilizar a prestação desses serviços nessa modelagem (torná-lo muito mais caro ao consumidor - impacto sobre a demanda que poderia levar a redução dos ganhos do ofertante), pois uma empresa de video por demanda que tenha $1.000^{80}$ títulos a disposição do usuário deve pagar, a princípio, $\mathrm{R} \$ 7.291,25^{81}$ por cada um desses títulos, considerando que os títulos sejam todos estrangeiros e não se aplicando aqui o disposto no art. 40, II, b da MP 2.228-1/2001 ${ }^{82}$. Para início de operação, neste caso, a empresa deveria arcar inicialmente com custo de $\mathrm{R} \$ 7.291 .250,00$ a título de Condecine, dado que seu pagamento é requisito fundamental para obtenção da licença de comercialização/veiculação de obras audiovisuais, de acordo com o art. 28, 29 e 32 da MP 2.228-1/2001. Esse custo tributário inicial é alto (fora a incidência de outros tributos e o valor de aquisição dos filmes em si, lembrando que deve ser renovado a cada 5 anos (art. 33, § $3^{\circ}$, I da MP 2.228-1/2001 ${ }^{83}$ ) e que novos filmes se inserem no portfólio dessas empresas com o passar do tempo).

Além disso, em termos estratégicos, o VOD é visto como uma possibilidade de pulverizar e diversificar a oferta de conteúdos audiovisuais, dada suas características (barreira entrada mais

\footnotetext{
${ }^{80}$ Segundo informações da imprensa, hoje a empresa Netflix possui em torno de 25.000 itens disponíveis aproximadamente 25.000 obras audiovisuais. Isso pode fazer com que tenhamos uma referência real de forma a saber qual poderia ser $\mathrm{o}$ custo tributário de Condecine nestes casos. Fonte http://tvefamosos.uol.com.br/noticias/ooops/2016/02/18/fim-do-misterio-saiba-quantos-filmes-e-episodios-ha-nanetflix-no-brasil.htm

${ }_{81}$ Para fins de simplificação, usamos os valores relacionados ao segmento de vídeo doméstico.

${ }^{82}$ MP 2.228-1/2001 - "Art. 40. Os valores da CONDECINE ficam reduzidos a...: II - trinta por cento, quando se tratar de... b) obras cinematográficas e videofonográficas destinadas à veiculação em serviços de radiodifusão de sons e imagens e cuja produção tenha sido realizada mais de vinte anos antes do registro do contrato no ANCINE...;

${ }^{83}$ MP 2.228-1/2001 "Art. 33. A Condecine será devida para cada segmento de mercado, por: (Redação dada pela Lei $n^{\circ} 12.485$, de 2011)...

... $\S 3^{\text {o }}$ A Condecine será devida: (Redação dada pela Lei n ${ }^{\circ} 12.485$, de 2011) (Produção de efeito) ....I - uma única vez a cada 5 (cinco) anos, para as obras a que se refere o inciso I do caput deste artigo; (Incluído pela Lei n ${ }^{\circ}$ 12.485, de 2011) BRASIL. MP no 2.228-1 2015.
}

Revista de Finanças Públicas, Tributação e Desenvolvimento - RFPTD, v. 6, n.6, 2018 


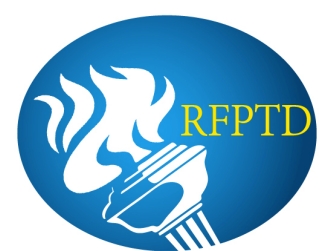

baixa se comparada a outros segmentos), em virtude principalmente, das facilidades da internet (inovação tecnológica), inclusive com a possibilidade de surgimento de segmentos específicos. Nesse sentido, seria possível a existência de um "Netflix" só de filmes de ação, de "filmes de arte" ou de "filmes iranianos", por exemplo. No entanto, considerando a forma de cobrança da Condecine sobre este segmento (valor fixo por cada título da empresa, com renovação a cada 5 anos), pode ensejar num aumento de barreira a entrada ${ }^{84}$, dificultando o aparecimento de novas empresas e a diversificação supracitada (um dos objetivos da Ancine, notadamente os previstos no art. $6^{\circ}$, VI e VIII ${ }^{85}$ ). Vale lembrar não se verificam ganhos de escala (economia de escala) significativos que justificassem este aumento da barreira, dado que, na verdade, advém, neste caso, por causa da incidência da Condecine; não provem de uma característica inerente do mercado. Num cenário onde só as grandes empresas (as majors como FOX, Warner, a própria Netflix ${ }^{86}$, hoje) atuassem no VOD, talvez essas empresas pudessem absorver sem grandes problemas este custo tributário. Mas para o objetivo da diversificação, não. Ademais, o aumento do custo fatalmente implicaria em aumento do preço e redução da demanda.

\footnotetext{
${ }^{84}$ Barreiras à entrada são dadas pela medida na qual, no longo prazo, as firmas estabelecidas podem elevar seus preços acima do nível de custo mínimo de produção sem induzir a entrada de outra firma. Outra definição de Barreiras à entrada é aquela que a define como qualquer fator em um mercado que ponha um potencial competidor eficiente em desvantagem com relação aos agentes econômicos estabelecidos. A ideia básica é que a elevação dos preços está limitada pela ameaça que a entrada de novos concorrentes exerce sobre as firmas já existentes, visto que estes podem ser atraídos pelos lucros elevados que as últimas estariam auferindo. Esta ameaça, por sua vez, pode ser mais ou menos intensa a depender do grau de dificuldade - ou facilidade - que um eventual entrante enfrenta para vir a atuar no mercado em questão. Assim, falar na existência de barreiras à entrada equivale a propor que, em determinadas condições, os lucros elevados são auferidos por um grupo de empresas em um mercado de oligopólio não acessíveis a novos investidores no setor produtivo em foco. Estas vantagens se refletem na capacidade de elevar, persistentemente os preços acima do nível competitivo sem atrair novas firmas para a indústria em questão. As barreiras à entrada na qual nos referimos aqui diz respeito ao fato de custo da Condecine ser um impeditivo para que novas empresas entrem no mercado, criando vantagem aos agentes já estabelecidos, especificamente, no segmento de vídeo por demanda programado, ainda que hoje há poucas empresas e que essa análise leve em conta possíveis e futuras dificuldades tendo em vista a cobrança de Condecine licença para empresas desse segmento. Conceituação de barreiras a entrada com base em MARTINS, Vinicius .Alves .Portela - Regulação e defesa da concorrência. Ed Forense. $1^{\mathrm{a}}$. Ed. 2014.

${ }^{85}$ MP 2.228-1/2001 “Art. $6^{\circ}$ A ANCINE terá por objetivos: VI-estimular a diversificação da produção cinematográfica e videofonográfica nacional e o fortalecimento da produção independente e das produções regionais com vistas ao incremento de sua oferta e à melhoria permanente de seus padrões de qualidade...

VIII - garantir a participação diversificada de obras cinematográficas e videofonográficas estrangeiras no mercado brasileiro;" BRASIL. Presidência da República. MP no 2.228-1 de 0609 2001. Estabelece princípios gerais da política nacional, do cinema, cria o conselho superior do cinema e a agência nacional do cinema - ancine, institui o programa de apoio ao desenvolvimento do cinema nacional - Prodecine, autoriza a criação de fundos de financiamento da indústria cinematográfica nacional - funcines, altera a legislação sobre a contribuição para o desenvolvimento da indústria cinematográfica nacional e dá outras providências. Brasília, DF., 2001 Disponível em: $<w w w$. planalto.gov.br>. Acesso em: 15 fev. 2011.

${ }^{86}$ As empresas que atuam em VOD no Brasil hoje, vide em https://oca.ancine.gov.br/outras-midias - Listagem de serviços de vídeo sob demanda (VOD) disponíveis no Brasil. Há um total de 52 empresas, sendo que oferecido gratuitamente por 7 dessas empresas; o resto, depende de assinatura.
} 


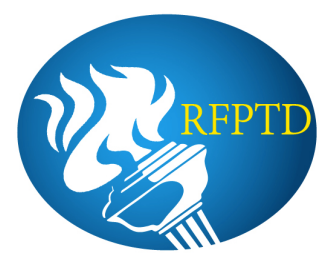

Outra consequência, há de se avaliar o aumento do valor arrecadado da Condecine, o que seria um efeito positivo, considerando o aumento do número de contribuintes. Mas vale destacar que seria necessário ter os dados de quantos títulos, por empresa (são 52 empresas registradas na Ancine que prestam o serviço de VOD) de forma a se saber o efetivo aumento de arrecadação, inclusive para fins de comparação com os efeitos citados anteriormente.

Assim, analisando do ponto de vista pragmático os efeitos e as consequências prováveis da incidência da Condecine Licença sobre esse segmento, num modelo análogo ao que ocorre com o vídeo doméstico atualmente, a intervenção da CIDE-Condecine Licença e sua incidência poderia inviabilizar esse modelo de negócio, pelo menos para algumas das empresas desse segmento, notadamente novas entrantes ${ }^{87}$ que poderiam ampliar e melhorar a concorrência no mesmo, causando uma redução de preço e melhora de bem estar para o consumidor, como dito ${ }^{88}$. Assim, nota-se a possibilidade de violação aos princípios da livre concorrência (art. 170, IV da CFRB), tendo em vista o aumento desproporcional do custo para que ofertantes atuem nesse mercado; a livre iniciativa (art. 170, caput), pois a incidência aumenta o custo inicial da empresa, especialmente de novos entrantes, dificultando o aumento de novos ofertantes que poderiam potencializar a livre concorrência; defesa do consumidor (tendo em vista o aumento do preço do serviço que pode vir a ser significativo, considerando a forma de tributação, reduzindo a demanda em face do aumento do preço; ou a redução da oferta - que também tem relação com a livre iniciativa). Além de atingir os princípios acima, ligados ao art. 170 da CRFB, temos também uma violação a igualdade ${ }^{8990}$ tributária, de forma inversa ${ }^{91}$. Ainda que haja discussão

\footnotetext{
${ }^{87}$ Como dito na nota acima, 7 empresas das 52 fornecem o serviço de forma gratuita. A incidência da Condecine nos moldes previstos hoje, nestes casos, também poderia ser ainda mais maléfica.

${ }^{88}$ Há de se considerar que esse modelo de negócio possui custos, de fato, menores (custos iniciais e custos irrecuperáveis) que poderiam incentivar a entrada de empresas menores, aumentando a concorrência e a diversificação de oferta de conteúdo, o que é um dos objetivos da Ancine, de acordo com o art. $6^{\circ}$, VI e VIII da MP 2.228-1/2001 neste setor. Os custos menores seriam os relativos à transmissão e estoques de filmes, basicamente, de forma a que pudesse representar, de fato, um aumento de concorrência na disponibilização de conteúdos audiovisuais e a segmentação referida no texto.

${ }^{89}$ Igualdade que trabalhamos é a igualdade princípio. no que se refere a sua natureza normativa, pode ser visto como:

1-POSTULADO - Norma que verte parâmetros para a aplicação de outra. Uma metanorma; norma que orienta o interprete na aplicação de outras normas, que é critério para a aplicação de outras);

2- PRINCÍPIO - Igualdade como uma norma, um princípio (explica que a igualdade é garantidora de um ideal de chances - objeto de aplicação - busca de um estado ideal)

3 - REGRA - Igualdade como norma objeto de aplicação, tal como acima, mas que usa determinadas medidas de comparação - ou seja, norma material que pré-exclui matérias do âmbito da competência do poder legislativo, o qual deve seguir, ao fazer regras, esta regra relativa a igualdade. Por exemplo, regras pautadas em distinções quanto ao exercício profissional. Neste caso, a CF/1988 prescreve que não pode haver regra que leve em consideração como medida de comparação essas distinções, porque violadora da isonomia, no âmbito de nossa constituição. Com base em:

AVILA, Humberto. Teoria da Igualdade Tributária. 1ª Edição. São Paulo. Ed. Malheiros., 2007, p. 134-136.
}

Revista de Finanças Públicas, Tributação e Desenvolvimento - RFPTD, v. 6, n.6, 2018 


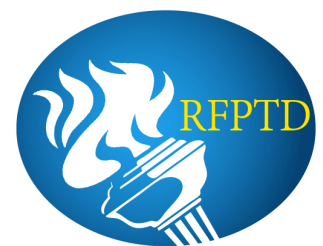

sobre a possibilidade de aplicação desse princípio às $\mathrm{CIDEs}^{92}$, entendemos ser possível ${ }^{93}$, ocorrendo neste caso, pois se trata igualmente agentes que se encontram em posição desigual, em virtude da forma de cobrança feita por valor fixo. ${ }^{94}$ No exemplo em que citamos, tanto uma grande empresa, como uma nova entrante que quisesse atuar neste segmento, deveria incorrer no custo de Condecine no mesmo valor - $\mathrm{R} \$ 7.291 .250,00 \mathrm{O}$ custo em alguns casos chega a ser desproporcional para algumas empresas ${ }^{9596}$,

\footnotetext{
${ }^{90}$ A Igualdade, antes de ser um princípio do direito ou princípio previsto na Carta Magna brasileira, é valor jurídico, colocando-se como entidade autônoma, posicionado ao lado de outros valores como econômicos, artísticos, etc. Os valores jurídicos de uma forma geral possuem as seguintes características básicas: abertura, a objetividade; a parcialidade, entre outros - com base em -TORRES, Ricardo Lobo Tratado de Direito Constitucional Financeiro e Tributário - volume II - Valores e princípios Constitucionais Tributários. 1ª. Edição. Ed renovar. RJ, 2005, p. 41. ${ }^{91}$ Gabriel Lacerda Troianelli ensina que esta é pouco estudada no direito tributário, sendo que esta expressão traduz a idéia de tratamento desfavorável, comparativamente, a outras objetivamente iguais, imposto a realidades jurídicas que, em razão de sua nacionalidade ou território que se localizam tem ligação jurídica privilegiada. TROIANELLI, Gabriel Lacerda. A nao-incidencia de IPI na importação de bem mediante leasing sem opção de compra.
} RDDT $15 \mathrm{r} 4, \mathrm{jul} / 08, \mathrm{p} .40$.

${ }^{92}$ Tipke (2002, p. 39) leciona:

"Em todos os lugares do mundo certamente encontram-se normas extrafiscais (intervencionistas, dirigistas, regulatórias e instrumentais) em leis tributárias. Elas violam o princípio da capacidade contributiva, especialmente por motivos de política econômica, cultural, sanitária, ambiental. A maioria dessas normas beneficia grupos específicos de contribuintes." ${ }^{92}$ Yamashita $(2002$, p. 62), no mesmo sentido, relata: "Assim, se a finalidade extrafiscal de certos tributos ou normas tributárias consistem em equilibrar a balança comercial, penalizar o poluidor, desincentivar o fumo ou o alcoolismo, ou incentivar a contratação de deficientes físicos, tais tributos deixam, em parte, a seara do direito tributário para invadir o direito econômico, o direito ambiental, o direito previdenciário, o direito trabalhista, nos quais não faz sentido em falar em justiça fiscal e de princípio da capacidade contributiva. Nesses casos, trata-se de outra espécie de justiça: justiça social.” - YAMASHITA, Douglas; TIPKE, ${ }_{92}^{K}$ laus. Justiça fiscal e princípio da capacidade contributiva. São Paulo: Malheiros, 2002. P. 39.

${ }^{93}$ No sentido de que a igualdade pode ser aplicada às contribuições, Schoueri (2004 p. 37/144) afirma: "O princípio da igualdade estabelece que todos aqueles que estão na mesma categoria profissional pagarão a mesma contribuição, todos que estão na mesma categoria econômica pagarão a mesma contribuição, enfim, todos aqueles que estão na mesma categoria de referibilidade pagaram a mesma CIDE. E entre aqueles que estão na mesma categoria? Dentre aqueles que estão atingidos pela intervenção no domínio econômico, como distinguir uns e outros? Sob o nosso ponto de vista, esta distinção deve ser feita pelo princípio da capacidade contributiva..." SCHOUERI, Luis Eduardo. Exigências da CIDE sobre Royalties e Assistência técnica ao exterior. RET 37/144, junho/04.

E também Gama (2003 p. 156): “...providência fundamental neste sentido é perceber os diferentes modos de identificar o respeito à igualdade, segundo a natureza do tributo, pois a aplicação desse princípio às contribuições será diversa daquela feita em relação aos impostos...nessa linha de pensamento, o princípio da igualdade surge como prescrição que determina a escolha dos contribuintes entre aqueles que integrem um mesmo grupo econômico, bem como impondo que sujeitos em situação análogo contribuam com prestações tributárias semelhantes...(grifo nosso)" GAMA, 2003.p.156.

${ }_{94}^{4}$ Ávila (2009, p. 194) cita, analisando estruturalmente a igualdade, que: "A finalidade a ser buscada deve ser demonstrada, sem ambiguidade ou contradição, mediante a indicação do suporte expresso ou implícito, cujo significado preliminar permita aferir asua previsão em nível constitucional...A igualdade só é assegurada se a lei, além de aplicada de modo uniforme, for isonômica em seu conteúdo, isto é, não diferencie os contribuintes senão por meio de fundadas e conjugadas medidas de comparação, atreladas a finalidades constitucionalmente postas..." AVILA, Humberto. Teoria da Igualdade Tributária. Ed. Malheiros. $2^{\mathrm{a}}$. Edição, 2010, p. 194.

95،....a constitucionalidade de tributos utilizados de forma instrumental para a obtenção de objetivos estatais deve ser aferida pelo controle de sua proporcionalidade, ou seja, se o tributo é adequado ao atingimento do fim, se é 


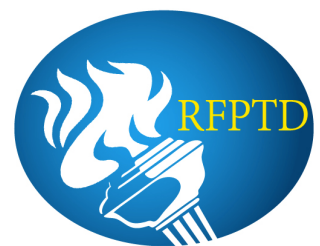

Há consequências também no caso da NÃO-incidência. Vamos analisá-las, considerando outras empresas do audiovisual que, efetivamente, pagam a Condecine Licença e atuam em outras janelas (ou segmentos de mercado como cinema, videodomestico, tv, etc.) competindo diretamente com as empresas de VOD.

Como relatado no tópico 2 , há fortíssima concorrência entre as janelas (segmentos de mercado no setor audiovisual como cinema, vídeo domestico, vídeo por demanda, TV paga, TV Aberta, etc.). E em muitos desses segmentos, há cobrança de Condecine (exceto nos casos de isenções legalmente concedidas ${ }^{97}$ ). No vídeo doméstico (segmento com maior semelhança ao de “vídeo on demand"), há incidência plena de Condecine, sendo este segmento o mais afetado pela concorrência $^{98}$ causada pelo VOD, pela similaridade entre os dois serviços oferecidos pelos agentes desses segmentos, conforme comentado no tópico 2. Entretanto, não há incidência de Condecine sobre VOD hoje.

A consequência direta é a criação, pela não incidência, de uma vantagem competitiva às empresas que atuam no VOD, em detrimento das que atuam em outro segmento, ainda que sejam

necessário para o objetivo almejado e, ainda, se não há outras formas menos gravosas para se atingir o mesmo desiderato. ADAMY, 2018. p. 314.

96 A proporcionalidade é composto de 3 subprincípios; Adequação ou idoneidade - $\mathrm{O}$ ato administrativo restritivo de direito - restrição operado pelo ato administrativo ou pela lei deve ser apta a atingir os fins pretendido por aquele ato; Necessidade ou exigibilidade - Dentre todos os meios existentes para atingir a finalidade pretendida pela administração pública, deve ser escolhido aquele menos gravosos, menos restritivos aos direitos dos administrados, dentre todas as opções disponíveis ao administrador público. A que menos impacte nos direitos fundamentais dos administrados; e Proporcionalidade em sentido estrito - Demanda uma análise de custo benefício da medida restritiva. Para uma determinada medida restritiva passar por esse teste, as vantagens decorrentes da restrição devem superar as desvantagens. Um caso que bem exemplifica essa questão julgado pelo STF é a relativa à exigência de que botijão de gás fosse pesado na frente dos consumidores e estes deveriam receber um desconto proporcional ao peso efetivamente existente no botijão. STF entendeu que esta não passava pelo teste de proporcionalidade em sentido estrito. Os benefícios decorrentes da livre iniciativa não justificariam o grau de dificuldade que trazia a medida para comércio de botijão. Embora adequada à proteção do consumidor, e talvez necessária, a restrição a livre iniciativa que não traria tanto benéficos assim aos consumidores (ADI N. 855-PR).

${ }_{97}^{97}$ Vide art. 39 da MP 2.228-1/2001.

98 Os números indicam quedas sucessivas nos números de DVDs e blueray lançados. Esses dados, muito provavelmente (ao menos em parte), são causados pela concorrência efetuada pelas outras janelas, notadamente o VOD, dada a substituibilidade entre esses segmentos e o serviço por ele oferecido, com base na teoria microeconômica neoclássica, onde o bem substituto faz reduzir a demanda do outro que o substitui. Observe a tabela:

\begin{tabular}{|l|l|l|l|}
\hline Ano & Blu-Ray & DVD & Total \\
\hline $\mathbf{2 0 1 0}$ & 434 & 1013 & 1447 \\
\hline $\mathbf{2 0 1 1}$ & 439 & 1130 & 1569 \\
\hline $\mathbf{2 0 1 2}$ & 455 & 1038 & 1493 \\
\hline $\mathbf{2 0 1 3}$ & 441 & 885 & 1326 \\
\hline $\mathbf{2 0 1 4}$ & 284 & 584 & 868 \\
\hline $\mathbf{2 0 1 5}$ & 283 & 528 & 811 \\
\hline $\mathbf{2 0 1 6}$ & 141 & 311 & 339
\end{tabular}

Dados disponíveis em - <https://oca.ancine.gov.br/outras-midias> acesso em 08 de abr. 2018.

Revista de Finanças Públicas, Tributação e Desenvolvimento - RFPTD, v. 6, n.6, 2018 


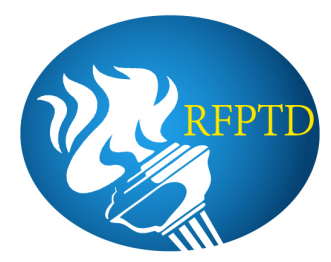

concorrentes, pois o não pagamento da Condecine permite a diminuição de seu custo e consequentemente uma possível diminuição no preço de oferta de seu serviço (vantagem na concorrência); ou aumento da margem de ganho em função do custo menor.

Analisando os princípios jurídicos relacionados a esse efeito, observa-se mais uma vez a violação a livre concorrência e a livre iniciativa (agora considerando comparativamente as vantagens de custo que os atuantes no segmento de VOD auferem sobre as empresas que atuam em outros segmentos). Além disso, há violação à igualdade, novamente, na medida em que a diferenciação entre os atuantes em VOD e os que não atuam não se dá com base em critérios considerados pelos autores que tratam do tema ${ }^{99}$ - constituindo-se num verdadeiro privilegio odioso, valendo destacar, exemplificativamente, a semelhança do ponto de vista de atuação entre empresas que atuam no vídeo doméstico.

Há uma violação à legalidade também, tendo em vista a ocorrência do fato gerador da exação. Uma argumentação de viés formalista ${ }^{100}$ poderia levar a conclusão de que, se os agentes incorrem num dos fatos geradores (licenciamento, especificamente, com intenção comercial Art. 32, I da MP 2.228-1/2001), devem $\operatorname{pagar}^{101}$ a Condecine Licença. Mas especificamente quanto a este argumento, por mais que seja argumento válido, real, especialmente no campo tributário e da influência que tem o princípio da legalidade no estudo do direito tributário, não resolve nosso problema de pensar a possibilidade da tributação (e especificamente a forma como está pode se dar) a partir dos efeitos dessa nos agentes que operam no mercado, especialmente pelo fato de que é um tributo que tem como função intervir no domínio econômico, corrigindo descompassos econômicos e falhas de mercado ${ }^{102103}$.

\footnotetext{
99 Ávila (2009, p. 194) cita, analisando estruturalmente a igualdade, que: "A finalidade a ser buscada deve ser demonstrada, sem ambiguidade ou contradição, mediante a indicação do suporte expresso ou implícito, cujo significado preliminar permita aferir a sua previsão em nível constitucional...A igualdade só é assegurada se a lei, além de aplicada de modo uniforme, for isonômica em seu conteúdo, isto é, não diferencie os contribuintes senão por meio de fundadas e conjugadas medidas de comparação, atreladas a finalidades constitucionalmente postas..." AVILA, 2010, p. 194.

${ }^{100}$ Sobre o tema, vide artigo do professor Sergio Andre Rocha - o que é formalismo tributário? $<$ http://www.academia.edu/32184986/Estudos_de_Direito_Tribut\%C3\%A1rio> Acesso em 10 abr. 2018.

${ }^{101}$ Ainda quanto ao aspecto formal e/ou literal, há a possibilidade de defesa de não-incidência da Condecine sobre o referido segmento em virtude de o art. $1^{\circ}$, VI da MP 2.228-1/2001 não trazer textualmente o segmento de mercado de vídeo por demanda; apesar da possibilidade de enquadramento dessas obras no segmento de outros mercados, possibilitando o pagamento.

${ }^{102}$ Falhas de mercado é termo usado pela microeconômica neoclássica ligada a teoria geral do equilíbrio alinhada ao equilíbrio de mercado entre oferta e demanda, a qual dá origem ao conceito de concorrência perfeita. Assim, aquela situação ou mercado que, por determinadas características como poder de mercado, assimetrias de informação, ou onde ocorrem externalidades ou onde se verifica a presença de bens públicos em sentido econômico (bens não-rivais e não-exclusivos), temos a ocorrência de falhas de mercado que são situações em que, naturalmente o equilíbrio de mercado não será alcançado, demandando, assim, intervenção regulatória do estado de forma a corrigi-las. As falhas
} 


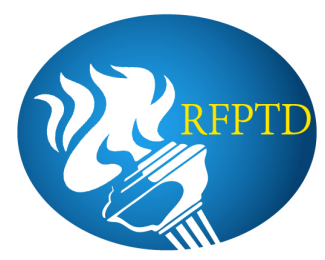

Por fim, devemos relatar a perda de arrecadação pela não incidência da Condecine no segmento de VOD, diminuindo a arrecadação do FSA sem motivo que justifique essa perda financeira.

Esse tratamento diferenciado não encontra, a princípio, qualquer fundamento na CRFB/1988 que justifique esse tratamento desigual e violador da igualdade como demonstrado entre estes sujeitos que se encontram neste mesmo domínio econômico (cobrança para uns; não cobrança para outro, ainda que incorram no fato gerador).

Assim, analisando efetivamente as possíveis conseqüências relativas à incidência e a não incidência, da Condecine Licença sobre o segmento de VOD, inclusive comparativamente aos efeitos econômicos sobre todo o domínio econômico do audiovisual e seus agentes, temos possíveis violações a princípios nos quais a CIDE deveria favorecer (art. 170 da CF/1988 como livre concorrência, livre iniciativa, etc.) e não prejudicar, o que aumenta ainda mais a complexidade da análise.

A etapa 3 relativa ao rankeamento da melhores consequências fica prejudicada, tendo em vista que ambas as decisões (etapa anterior ao rankeamento) implicam em consequências que, possivelmente, levam a resultados violadores de princípios constitucionais intimamente relacionadas à CIDE (Art. 170 - notadamente a livre concorrência) além da igualdade tributária e a própria legalidade (no caso de não incidência).

E isso nos remete ao fato de que não é a tributação, em si, a causa do problema: mas a forma como vem sendo feito, considerando a atual estrutura da Condecine Licença,

de mercado são caracterizadas pelo impedimento da possibilidade da maior eficiência de uma relação econômica. Tal título se refere aos alegados fracassos da teoria liberal da economia, que preconizava o princípio do Laissezfaire, por isso se designando "falha""

${ }^{103} \mathrm{O}$ fato do segmento outros mercados conter alto grau de indeterminação, alguns autores também o consideram como violador da legalidade estrita, tipicidade cerrada que, segundo alguns autores (Alberto Xavier, por todos) representam as bases do direito tributário. Logo, ao se atrelar o pagamento do segmento de VOD a este, há a possibilidade de questionamentos a este aspecto, já que Outros Mercados é conceito que será definido em norma infra legal, ainda que não particularmente não consideremos que a presença desse conceito jurídico indeterminado na lei impeça a normatização infra-legal pela entidade competente), justamente porque ele tem a finalidade de se adequar a crescente e rápida inovação tecnologia no qual submete-se o setor audiovisual. No sentido da possibilidade de que a lei faça previsões gerais e permita o detalhamento por instrumento infra-legal temos o caso da contribuição SAT qual transcrevemos a ementa: RECURSO EXTRAORDINÁRIO 684.261 PARANÁ RECURSO EXTRAORDINÁRIO. DIREITO PREVIDENCIÁRIO. CONTRIBUIÇÃO. SEGURO ACIDENTE DE TRABALHO. RISCOS ACIDENTAIS DO TRABALHO. FATOR ACIDENTÁRIO DE PREVENÇÃO. LEGALIDADE TRIBUTÁRIA. DISCUSSÃO SOBRE A FIXAÇÃO DE ALÍQUOTA. DELEGAÇÃO PARA REGULAMENTAÇÃO. RESOLUÇÃO DO CONSELHO NACIONAL DE PREVIDÊNCIA SOCIAL. PRECEDENTE DO SUPREMO NA RE 343.446-2, RELATOR MINISTRO CARLOS VELLOSO. REPERCUSSÃO GERAL RECONHECIDA. REAFIRMAÇÃO DA JURISPRUDÊNCIA $<$ http://stf.jus.br/portal/jurisprudenciarepercussao/verPronunciamento.asp?pronunciamento $=4019040>$ acesso em 20 mar. de 2018; 


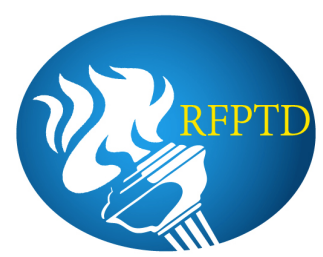

especialmente no que se refere ao aspecto quantitativo do fato gerador da Condecine Licença, como procuraremos demonstrar agora.

\section{3- Breves considerações sobre a estrutura tributária da Condecine licença e sua relação}

com as possíveis consequências da incidência e não incidência da Condecine Licença no mercado de VOD

Diante do exposto, nota-se que muitos dos problemas apontados originam-se da estrutura desse tributo, especialmente no que se refere ao aspecto quantitativo dessa exação (base de cálculo e alíquota utilizada). O fato de ser cobrado por título (filme) e por um preço fixo (tributo fixo), com valor variando de acordo com a nacionalidade, classificação e finalidade da obra publicitária ou não publicitária, nos moldes de cobrança da espécie taxa (art. 145, II da CF/1988), traz problemas quanto a intervenção provocada pela incidência. Na verdade, há uma semelhança com a espécie taxa (base de cálculo e alíquota) que, independentemente das possíveis origens ${ }^{104}$ que levaram a estruturação da Condecine Licença dessa maneira, estão na base de grande parte das consequências apontadas, especialmente as que levam a violação dos princípios do art. 170 da CRFB e os afetos ao direito tributário (seja na incidência, seja na não incidência sobre o segmento de VOD).

Outros trabalhos ${ }^{105}$ já apontaram que a cobrança de um valor fixo a título de Condecine Licença, independentemente do sujeito que está pagando (dado que a referência é o filme em si que está sendo veiculado, independentemente de qual filme é, suas características, capacidade de geração de renda, etc.) fere a igualdade entre os atuantes no segmento de salas de exibição, não estando em consonância com a capacidade contributiva dos agentes econômicos que atuam neste setor. E, neste caso, tem-se uma violação da igualdade, ocasionada pela forma de incidência da Condecine Licença, considerando sua estrutura.

\footnotetext{
${ }^{104} \mathrm{O}$ fato de a Condecine Licença ter nascido com base de cálculo semelhante à utilizada em determinadas taxas pode ter relação com o fato de ser agencia reguladora o qual, grande parte da doutrina ${ }^{104}$, à época, entendia que como fator importante para sua autonomia e independência financeira e funcional, tivesse uma taxa um recurso próprio que garantisse sua autonomia. Este raciocínio parece fazer sentido quando olhamos para a redação original do art. 34 da MP 2.228-1/2001, claramente inconstitucional, pois que destinava recursos de CIDE para custeio, quando há taxa para fazer isso. Além disso, a Condecine do art. 32, I é condição para obtenção de licença de veiculação, distribuição de conteúdo audiovisual com intenção comercial (registros obrigatórios previstos no art. 28 e seguintes da MP 2.228-1/2001), o que reforça mais uma vez a origem o nascimento dessa CIDE com características de taxas quanto a seu aspecto quantitativo (semelhante as taxas provenientes do exercício de poder de polícia encontrados no artigo 18 da lei 9.961/2000, exemplificativamente). Em virtude dessas, tentamos elucidar alguns dos elementos que podem ter contribuído para que base de cálculo da Condecine tenha as características citadas.

${ }^{105}$ MARTINS, Vinícius Alves Portela. A relação do princípio da isonomia com as contribuições de intervenção no Domínio Econômico. O caso da Condecine Licença. Revista tributária e de finanças públicas. Coordenação Evaldo Pereira de Brito. Ed. Revista dos tribunais. Ano 20 104. São Paulo, 2012. P. 100-133.
} 


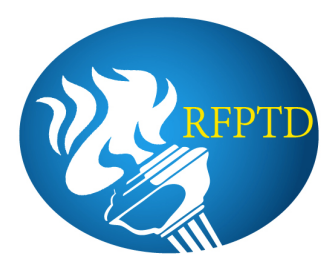

Assim, tanto para o VOD como para outros segmentos, parece-nos adequado o uso de uma alíquota ad valoren sobre uma determinada base de cálculo (por exemplo faturamento ou lucro da empresa), de forma a que a tributação seja mais adequada à diferença em si dos agentes atuantes sobre esse segmento (e não tomando como base num filme que, supostamente, seria uma unidade de medida fixa ${ }^{106}$ ), buscando-se respeitar a proporcionalidade e a igualdade entre os agentes desse domínio especifico, sob pena de que a intervenção ocasionada pela incidência tributária gere, por si só, descompassos econômicos, piorando falhas de mercado ${ }^{107}$ (por exemplo, criando barreiras à entrada) no setor sujeito a incidência da CIDE (no caso aqui, a Condecine).

\section{Conclusão}

Concluímos pela necessidade de revisão da estrutura tributária da Condecine Licença (art. 32, I da MP 2.228-1/2001) de forma a que se possa solucionar a pendência com relação a cobrança desta sobre os agentes que atuem no segmento de VOD, tendo em vista que ao analisar as consequências econômicas derivadas da incidência/não incidência dessa exação, observou-se uma intervenção negativa (considerando os princípios informadores da constituição válida desta CIDE) nesse segmento e em outros do audiovisual.

Descreveu-se características básicas do pensamento pragmático/consequencialista, de acordo com a literatura que trata do tema. Apontamos também algumas características e conceituações sobre o mercado audiovisual e o segmento de vídeo por demanda (inclusive o comparando com o segmento de vídeo doméstico), enfatizando as características econômicas do audiovisual, notadamente o segmento de VOD e vídeo doméstico.

Após uma breve descrição das características básicas das CIDEs/Condecine Licença, com fundamento na literatura especifica sobre o tema, de forma a conhecermos sua estrutura tributária e os princípios constitucionais que informam sua instituição válida, analisamos as principais consequências econômicas de sua possível incidência ou de sua real não-incidência sobre o segmento de vídeo por demanda, a luz dos critérios doutrinários sugeridos para realização de análises consequencialistas.

\footnotetext{
${ }^{106}$ Só a título de exemplo de exemplo, há filmes que fazem 50, 800, 1000 pagantes, enquanto outros fazem próximo de 11 milhões como o Tropa de Elite 2 da distribuidora Zazen).

${ }^{107}$ É a situação em que o custo marginal social não é igual ao benefício marginal. Essas falhas de mercado são em sua maioria situações opostas a da teoria da "mão invisível", na qual a busca pelo desejo individual pode acabar prejudicando a sociedade caso não haja um intervencionismo. Concorrência imperfeita, externalidades, informação assimétrica e mercados incompletos, são manifestações de falha de mercado.
} 


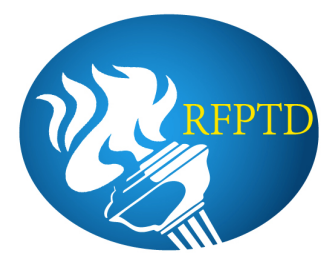

Chegou-se à conclusão que a intervenção no domínio econômico provocada pela cobrança e não cobrança da Condecine Licença sobre agentes de VOD é ruim (tendo em vista os princípios constitucionais que visa concretizar), podendo, em ambos os casos haver a violação dos princípios previstos no art. 170 da CF/1988 (notadamente a livre concorrência, a livre iniciativa e defesa do consumidor), tendo em vista os efeitos econômicos provocados no mercado em ambos os casos (incidência ou não incidência) como o tamanho do aumento do custo para as empresas, os impactos sobre a oferta e demanda que causam, a criação de vantagens competitivas não justificáveis, aumento das barreiras à entrada no segmento de VOD de forma desproporcional, entre outros. Impacta negativamente também nos princípios afetos ao direito tributário como a igualdade e a legalidade (este último no caso da decisão pela não incidência da Condecine sobre VOD, considerando a estrutura atual da Condecine Licença, apesar da ocorrência do fato gerador licenciamento). A violação a legalidade se dá pelo fato de ocorre o fato gerador e não há cobrança. Já a violação a igualdade, se dá tanto no que tange à incidência no âmbito do segmento de VOD (cobrança de valores iguais para agentes que se encontram em situações desiguais - violação inversa da igualdade) como pela não-incidência no segmento de VOD; neste caso, cria-se uma situação de desigualdade entre estes (que não pagam) e outros agentes do setor audiovisual, especialmente os que atuam no segmento de video doméstico, chamados ao pagamento, ainda que atuem no mesmo domínio econômico.

Sugere-se para resolver estes problemas e feitos uma revisão radical da estrutura tributária da Condecine Licença, a qual não deve utilizar como aspecto quantitativo de seu fato gerador alíquotas específicas (tal como ocorre nas taxas ou na CIDE-combustível), mas alíquotas ad valoren tendo como base característica inerente aos agentes e seu tamanho e peso dentro do setor do audiovisual como um todo o seu faturamento ou seu lucro. Essa conclusão fundamentase nos efeitos e consequências descritas (seja pela incidência ou não incidência no segmento de VOD) já extensamente analisados. Ademais, a obra audiovisual é variável entre si; diferentemente do que ocorre com as commodities - produtos homogêneos ${ }^{108}$ - como cimento, Petróleo, etc.). Possuem enormes diferenças, seja de custo de produção, seja da renda potencial e real que podem auferir em função, principalmente, do sujeito que a produz e da posição deste no mercado audiovisual como um todo. Logo, para se buscar uma tributação proporcional, igual no

\footnotetext{
108 “O produto[...]homogéneo...é, do ponto de vista dos consumidores, igual ao produto oferecido pelas restantes empresas da mesma indústria"- <https://pt.wikipedia.org/wiki/Concorr\%C3\%AAncia_perfeita $>$ Produto homogêneo é aquele onde não a diferenciação significativa do ponto de vista do consumidor. Por exemplo, feijão, açúcar, cimento, Petróleo, etc. Diferentemente de um produto heterogêneo como celulares, que são diferenciados entre si, tanto na qualidade como no preço.
}

Revista de Finanças Públicas, Tributação e Desenvolvimento - RFPTD, v. 6, n.6, 2018 


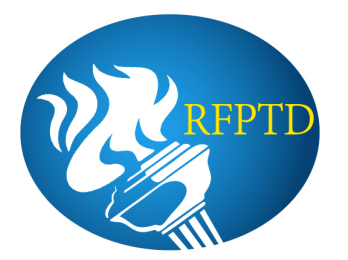

âmbito desse setor especifico, a Condecine licença não pode ter quanto ao aspecto quantitativo do fato gerador semelhante ao de taxas ou outras espécies da forma como estudado e descrito, sendo essa estrutura atual a principal responsável por todos os problemas verificados neste estudo.

Sugere-se, ao final, genericamente, a criação de parâmetros de constitucionalidade de CIDEs (inclusive a Condecine) que levem em conta os efeitos provocados pela incidência da mesma sobre um dado domínio econômico (num momento anterior à análise da aplicação da receita e os resultados gerados por esta), avaliando os efeitos econômicos desta sobre o domínio econômico no qual se quer intervir, formatando uma estrutura de tributo que, pela sua incidência, não cause descompassos econômicos, considerando as caraterísticas do mercado e dos agentes que o compõe, buscando melhorar a tributação e a respectiva intervenção a ser feita por essa importante espécie tributária, de forma a que não represente apenas um adicional de receita para a União ou que ocorra o observado no presente estudo. Este primeiro parâmetro deve ser somado a outro, importante, a ser desenvolvido em outro ensaio: a análise efetiva da aplicação dos recursos das CIDEs e os resultados gerados, de forma a verificar concretamente o nível de atingimento de seus objetivos e finalidades públicas que informam a válida instituição dessa espécie, que transita entre o direito tributário e o econômico e que, por isso, torna importante a analise consequencialista.

\section{Bibliografia}

ADAMY, Pedro. Instrumentalização do direito tributário. In. AVILA, Humberto.

Fundamentos do Direito tributário. $1^{a}$ Edição. Editora Marcial pons. SP, 2012. P. 305.

ATALIBA, Geraldo. Hipótese de incidência tributária., 4ª edição, RT, 1991

AVILA, Humberto. Teoria da Igualdade Tributária. 1ª Edição. São Paulo. Ed. Malheiros., 2007, p. 134-136.

BARROS, Leonardo Monteiro. Avaliação de empresas de cinema e estúdios cinematográficos. Dissertação de mestrado-FGV, 2009 


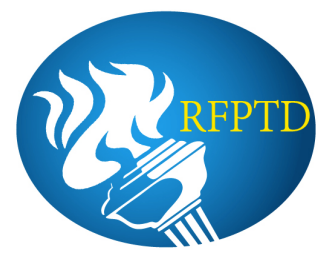

BAUMAN, Zygmunt. O mal-estar da pós-modernidade. Tradução Mauro Gama e Claudia Martinelli Gama. Rio de Janeiro: Jorge Zahar Ed., 1998a.

BAUMAN, Zygmunt. Modernidade e Ambivalência. Tradução Marcos Penchel. Rio de Janeiro: Jorge Zahar Ed., 1999.

BAUMAN, Zygmunt. Modernidade e Holocausto. Tradução Marcos Penchel. Rio de Janeiro: Jorge Zahar Ed, 1998b. -

BRANDO, Marcelo Santini. A crítica da vertente econômica à teoria de justiça de John Rawls. Revista de Direito da procuradoria Geral do RJ. Vol. 66, 2011.

. BRASIL. Presidência da República. Lei no 11.437 de 2812 2006. Altera a destinação de receitas decorrentes da Contribuição para o Desenvolvimento da Indústria Cinematográfica Nacional - Condecine, criada pela Medida Provisória no 2.228-1, de 6 de setembro de 2001, visando ao financiamento de programas e projetos voltados para o desenvolvimento das atividades audiovisuais; altera a Medida Provisória no 2.228-1, de 6 de setembro de 2001, e a Lei no 8.685 , de 20 de julho de 1993, prorrogando e instituindo mecanismos de fomento à atividade audiovisual; e dá outras providências. Brasília, DF. 2006. Disponível em: $<w w w$. planalto.gov.br>. Acesso em: 15 fev. 2014.

BRASIL. Presidência da República. MP no 2.228-1 de 0609 2001. Estabelece princípios gerais da política nacional, do cinema, cria o conselho superior do cinema e a agência nacional do cinema - ancine, institui o programa de apoio ao desenvolvimento do cinema nacional Prodecine, autoriza a criação de fundos de financiamento da indústria cinematográfica nacional Funcines, altera a legislação sobre a contribuição para o desenvolvimento da indústria cinematográfica nacional e dá outras providências. Brasília, DF., 2001 Disponível em: $<w w w$. planalto.gov.br>. Acesso em: 15 fev. 2016.

BRASIL. Presidência da República 5.172/1966. Dispõe sobre o Sistema Tributário Nacional e institui normas gerais de direito tributário aplicáveis à União, Estados e Municípios. Disponível em: <www. planalto.gov.br>. Acesso em: 15 fev. 2012. 


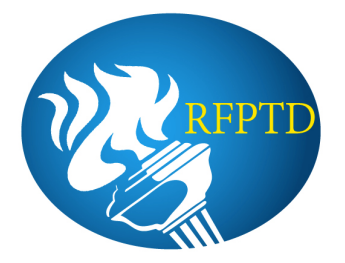

BRASIL. Presidência da República 10.336/2001. Institui Contribuição de Intervenção no Domínio Econômico incidente sobre a importação e a comercialização de petróleo e seus derivados, gás natural e seus derivados, e álcool etílico combustível (Cide), e dá outras providências. Disponível em: <www. planalto.gov.br>. Acesso em: 15 fev. 2012.

DE SANTI, Eurico Marus Diniz. A modulação do controle de constitucionalidade de novos tributos. Disponível em <https://www.conjur.com.br/2014-jul-10/eurico-santi-modulacaosupremo-criacao-tributo\#author>a. Acesso em 09 de Abr. 2018.

DIAS, Daniela Gueiros e LEAL, Fernando Angelo Ribeiro. Consequencialismo judicial na modulação de efeitos das decisões declaratórias de inconstitucionalidade nos julgamentos de direito tributário. Rev. Bras. Polít. Públicas, Brasília, v. 7, n 3, 2017 Disponível em $<$ https://www.publicacoesacademicas.uniceub.br/RBPP/article/view/4779/3604> . Acesso em 8 de abr. 2018.

DWORKIN, Ronald. A justice de toga. São Paulo: Martins Fontes, 2010.

FIANI, Ronaldo. Cooperação e conflito. Instituições e desenvolvimento econômico. $1^{\mathrm{a}}$. Edição. Ed Elsevier. Rio de Janeiro, 2011.

FREIRE, Alonso Reis. Odisseu ou Hercules? Sobre o pragmatismo e a análise econômica do direito de Richard A $\quad$ Posner. $\quad$ Disponível em $<$ http://periodicos.pucminas.br/index.php/DireitoSerro/article/view/1996/2179> acesso em: $01 \mathrm{de}$ abril.2018.

GRECO, Marco Aurélio. Contribuição de intervenção no domínio econômico: uma figura sui generis. São Paulo Ed. Dialética, 2000

Contribuição de intervenção no domínio econômico e figuras afins. Ed.

Dialética, 2001

KELLNER, Alexander Leonard Martins. A desconstitucionalização da análise de impacto regulatório como estratégia para sua implementação. In LEAL, Fernando e MENDONÇA, 


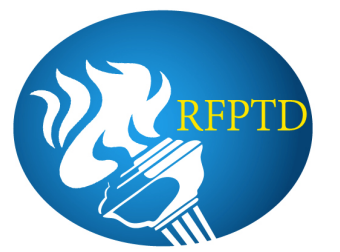

José Vicente Santos de. Transformações do Direito Administrativo: novas tecnologias e $\begin{array}{llll}\text { alternativas } & \text { regulatórias. } & \text { Disponível }\end{array}$ $<$ http://bibliotecadigital.fgv.br/dspace/handle/10438/18009>. Acesso em 8 de Abr. 2018. p. 25.

KINOUCHI, Renato Rodrigues. Notas Introdutórias ao pragmatismo clássico. Disponível em: $<$ http://www.scielo.br/pdf/ss/v5n2/a04v5n2.pdf> acesso em: 05 de abril.2018.

KRUGMAN, Paul; e WEELS, Robin. Microeconomia uma abordagem moderna. $3^{\text {a }}$. Edição. São Paulo. Editora Elsevier, 2014.

LEAL, Fernando. Considerar as consequências das decisões resolve? Uma análise crítica do PL 349/15. $\quad<\mathrm{http}: / / \mathrm{www}$.direitodoestado.com.br/colunistas/fernando-leal/considerar-asconsequencias-das-decisoes-resolve-uma-analise-critica-do-pl-34915> Acesso em 2 de fev. 2017. Vide também - ARGUELHES, Diego Werneck e LEAL, Fernando. Pragmatismo como [Meta]Teoria da Decisão Judicial: Caracterização, Estratégias e Implicações. In: Daniel Sarmento (Org.). Filosofia e Teoria Constitucional Contemporânea. Rio de Janeiro: Lumen Juris, 2009, p. 190.

LEAL, Fernando Angelo Ribeiro. Inclinações pragmáticas no direito administrativo: nova agenda, novos problemas. O caso do PL 349/15. In: LEAL Fernando e MENDONÇA, José Vicente. Transformações do direito administrativo: Consequencialismo e estratégias. Rio de janeiro. Editora FGV, 2016

MARTINS, Vinícius Alves Portela. AGÊNCIA NACIONAL DO CINEMA - ANCINE: Comentários à Medida Provisória $N^{0}$ 2.228-1/01, ao Decreto $N^{o} 4.121 / 02$ e à Lei $N^{o}$ 12.485/11 - Vol. 24. Ed Atlas. SP, 2015.

MARTINS, Vinícius Alves Portela. “A questão da (in)definição sobre incidência monofásica no caso de contribuições de intervenção no domínio econômico-CIDEs: o caso da Condecine" publicado na Revista dos tribunais No 98, 2011. 


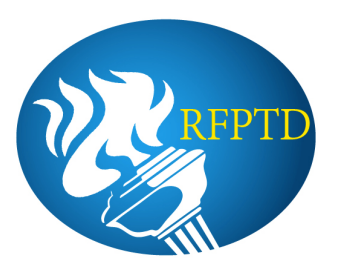

MARTINS, Vinícius Alves Portela. Regulação e defesa da concorrência. $1^{\text {a }}$. Edição. Rio de janeiro. Ed Forense, 2014.

MARTINS, Vinícius Alves Portela. Possibilidades de intervenção regulatória por parte de CIDEs: o caso especifico da Condecine

$<$. http://www.seae.fazenda.gov.br/premio-seae/edicoes-anteriores/edicao-2009/iv-premio-seae2009>. Brasília. IV Prêmio SEAE, 2009.

MARTINS, V.A.P. A contribuição para o desenvolvimento da indústria cinematográfica Condecine: uma contribuição sui generis? Revista Tributária e de Finanças Públicas, v. 110, p. 279-303, 2013.

MARTINS, Vinícius Alves Portela. A relação do princípio da isonomia com as contribuições de intervenção no Domínio Econômico. O caso da Condecine Licença. Revista tributária e de finanças públicas. Coordenação Evaldo Pereira de Brito. Ed. Revista dos tribunais. Ano 20104. São Paulo, 2012.

MELlO. Gustavo Miguez. Contribuições de Intervenção no Domínio Econômico: in pesquisas tributárias série 8. São Paulo: RT, 2002.

MENDONÇA, José Vicente Santos de. Direito Constitucional econômico: a intervenção do estado na economia à luz da razão pública e do pragmatismo. $1^{\mathrm{a}}$. Edição. MG-Belo Horizonte Editora Fórum. 2014. P. 48.

MENDONÇA, José Vicente Santos de. Dois futuros e meio para o projeto de lei de Carlos Ari. In: LEAL Fernando e MENDONÇA, José Vicente. Transformações do direito administrativo: Consequencialismo e estratégias. Rio de janeiro. Editora FGV, 2016

OLIVEIRA, Rafael Carvalho Rezende. A releitura do direito administrativo a luz do pragmatismo jurídico. rda - revista de Direito Administrativo, Rio de Janeiro, v. 256, p. 129-63, jan./abr. 2011. 


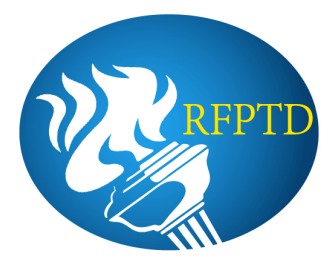

$<$ http://bibliotecadigital.fgv.br/ojs/index.php/rda/article/viewFile/8496/7245>; acesso em: 05 de abril. 2018. p.132

OLIVEIRA, José Marcos Domingues de. Contribuições Parafiscais, Finalidade e Fato Gerador. Revista Dialética de Direito Tributário, n. 73, outubro 2001. Dialética: São Paulo, 2001.

PARGENDLER, Mariana e SALAMA, Bruno Meyerhof. Direito e consequência no Brasil: em busca de um discurso sobre o método. rda - revista de Direito Administrativo, Rio de Janeiro, v. 262, $\quad$ p. $\quad 95-144, \quad$ jan./abr. 2013.

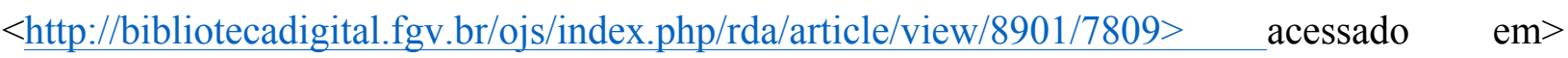
07/04/2018. P. 97.

PAULSEN. Leandro. Direito tributário: constituição e código tributário a luz da doutrina e da jurisprudência. Ed livraria dos advogados. Porto Alegre. 2009

POGREBINSCHI Thamy. Teoria social e política. 1ª Ed. RJ. Ed. Relume dumará, 2005.

POSNER, Richard. Law, pragmatism and democracy. Cambridge: Harvard University press, 2003.

Pragmatism $<$ https://plato.stanford.edu/entries/pragmatism/:> acesso em: 05 de abril. 2018.

RIBEIRO. Ricardo Lodi. As contribuições parafiscais e a validação constitucional das espécies tributárias. São Paulo. Revista dialética de direito tributário. VOL. 174, 2015.

RIBEIRO, Ricardo Lodi. Temas de Direito Constitucional Tributário. Editora LumienIuris . SP. 2009 , p. 1.

ROCHA, Sergio André. o que é formalismo tributário? $<$ http://www.academia.edu/32184986/Estudos_de_Direito_Tribut\%C3\%A1rio $>$ Acesso em 10 abr. 2018. 


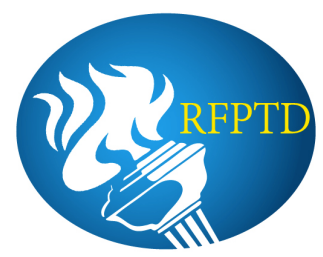

SCHOUERI, Luis Eduardo. Exigências da CIDE sobre Royalties e Assistência técnica ao exterior. RET 37/144, junho/04

SCHUARTZ, Luis Fernando. Consequencialismo Jurídico, Racionalidade Decisória e Malandragem. Rio de Janeiro. Revista de Direito administrativo. Vol. 248. Ed. Fundação $\begin{array}{lllll}\text { Getúlio } & \text { Vargas. } & 2008, & \text { p. } & 130 .\end{array}$ http://bibliotecadigital.fgv.br/ojs/index.php/rda/article/view/41531/40881 > acesso em: 01 de abril.2018.

SCHUMPETER, Joseph A. Capitalismo, Socialismo e Democracia. $1^{\text {a }}$. Edição. Rio de Janeiro: ZAHAR Editores, 1984.

STUCKERT, Gabriel. VOD: o bom e velho mercado de vídeo doméstico. Revista GEMInIS, São Carlos, UFSCar, v. 8, n. 2, pp.04-15, mai. / ago. 2017. Disponível em $<$ http://www.revistageminis.ufscar.br/index.php/geminis/article/view/293/260>. Acesso 11 de Abr. 2018.

TORRES, Ricardo Lobo; TORRES, Silvia Faber. Estudos e pareceres de direito tributário. Ed. Elsevier. RJ. 2014

TORRES, Ricardo Lobo. Tratado de Direito Constitucional Financeiro e Tributário volume II - Valores e princípios Constitucionais Tributários. 1 ${ }^{\mathrm{a}}$. Ed. Editora Renovar. Rio de Janeiro, 2005, p. 41-145-146.

YAMASHITA, Douglas; TIPKE, Klaus. Justiça fiscal e princípio da capacidade contributiva. São Paulo: Malheiros, 2002.

\section{Link da internet}

http://tvefamosos.uol.com.br/noticias/ooops/2016/02/18/fim-do-misterio-saiba-quantos-filmes-eepisodios-ha-na-netflix-no-brasil.htm acesso em 18 de Ma. 2018 https://oca.ancine.gov.br/outras-midias> acesso em 08 de abr. 2018.

$<$ http://stf.jus.br/portal/jurisprudenciarepercussao/verPronunciamento.asp?pronunciamento=4019 040> acesso em 20 mar. de 2018; <https://pt.wikipedia.org/wiki/Concorr\%C3\%AAncia perfeita> acesso em: 05 de fev.. 2018 
Revista de Finanças Públicas, Tributação e Desenvolvimento - RFPTD, v. 6, n.6, 2018 